\title{
ISOLATION AND CHARACTERIZATION OF INDIGENOUS BIOSURFACTANT PRODUCING BACILLUS AND STAPHYLOCOCCUS SPP. DURING MOTOR OIL DEGRADATION
}

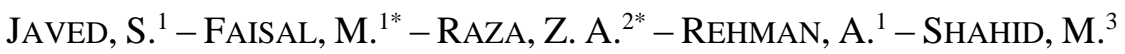 \\ ${ }^{1}$ Institute of Microbiology and Molecular Genetics, Faculty of Life Sciences, University of the \\ Punjab, Lahore-54590, Pakistan \\ ${ }^{2}$ Department of Applied Science, School of Science, National Textile University, Faisalabad- \\ 37610, Pakistan \\ ${ }^{3}$ Department of Bioinformatics and Biotechnology, Government College University, Faisalabad \\ 38000, Pakistan \\ ${ }^{*}$ Corresponding authors \\ e-mail:faisal.mmg@pu.edu.pk (Dr.M. Faisal),zarazapk@yahoo.com (Dr.Z.A.Raza) \\ (Received $1^{\text {st }}$ Jun 2021; accepted $28^{\text {th }}$ Oct 2021)
}

\begin{abstract}
The present study dealt with the isolation and characterization of some biosurfactant-producing bacterial strains obtained from motor oil contaminated soil samples collected from the local auto-workshops of Lahore. Thereby, four bacterial species were selected based on $\mathrm{CTAB} /$ methylene blue-agar, emulsification index, and drop-collapse assays, and then, biochemically identified as Staphylococcus hominis, Staphylococcus sp., Bacillus flexus, and Bacillus oceanisediminis, and confirmed through 16S rRNA gene sequencing. Fourier transform infrared spectroscopic analysis was done to track the surface chemistry of the isolated bacterial surfaces. The isolated bacterial strains were then employed at different concentrations $(1-3 \%, \mathrm{w} / \mathrm{v})$ of motor oil, and various temperatures, $\mathrm{pH}$ values, incubation intervals, and in the absence or presence of certain inhibitors like sodium dodecyl sulfate and the $\mathrm{Cr}(\mathrm{VI})$ ions. There observed a maximum of $81.8 \%(\mathrm{w} / \mathrm{w})$ oil degradation at $1 \%(\mathrm{w} / \mathrm{v})$ oil concentration with Staphylococcus sp. at $37^{\circ} \mathrm{C}, \mathrm{pH} 7$, and $96 \mathrm{~h}$ of incubation, whereas in the presence of $\mathrm{Cr}(\mathrm{VI})$ ions under the same physiological conditions, the oil degradation was suppressed to $6.0 \%(\mathrm{w} / \mathrm{w})$. The results demonstrate that the identified bacterial strains could effectively be used to bioremediate the motor oil-contaminated soil at drilling sites as well as in the aquifers.
\end{abstract}

Keywords: biodegradation, bioremediation, crude oil, emulsion, surfactant

\section{Introduction}

Surfactants, whether derived from chemical or biological origins, possess both hydrophilic and hydrophobic moieties which not only support emulsification but also decrease the surface and interfacial tensions (Raza et al., 2009; Sakamoto et al., 2017; Pinazo et al., 2019), and those of biological origin are called biosurfactants (Singh et al., 2020). They can modify the surface characteristics of certain substrates like surface adsorption, surface energy, and wettability. They can also enhance the bioavailability of hydrophobic substrates for their prompt degradation and biotransformation under certain fermentation conditions (Raza et al., 2007; Henkel and Hausmann, 2019). The biosurfactants represent an assorted class of surface-active molecules and are synthesized by diverse microbes under suitable culture conditions. They are valuable biological molecules with widespread attributes like biocompatibility, biodegradability, specific activity, activity in extreme environments, and so on. This makes them versatile green chemicals for a wide range of industrial and environmental applications (Khubaib et al., 
2021). The biosurfactants can effectively be employed in medical and industrial applications for emulsification, de-emulsification, encapsulation, enhanced recovery, and ore floatation processes (Gregorich et al., 2015; Naik et al., 2018). Thereby, glycolipids, lipopeptides or lipoproteins, phospholipids, biopolymeric surfactants, and fatty acids are the major varieties of structurally diverse biological surfactants produced by certain bacteria, yeast, and fungi (da Silva et al., 2020).

The rapid and careless use of synthetic chemical reagents has resulted in serious environmental concerns (Karlapudi et al., 2018). It has been well recognized that petroleum-based hydrocarbons and their derivatives like diesel, motor oil, mineral oil, engine oil, and their residues deteriorate the environment. Motor oil being a mixture of certain aromatics, cyclic alkanes, additives, and anticorrosive compounds, is difficult to degrade under ambient conditions (Sharma et al., 2019). Moreover, the used motor oil carries in it a rather enhanced proportion of heavy metals, carcinogenic compounds, toxic metals, and polycyclic aromatic hydrocarbons that cause serious threats not only to human beings but also to vegetation (Bhattacharya et al., 2019).

Different chemo-physical and biological techniques had been used for the degradation of hydrocarbons containing water and soil systems. One way is the emulsify the hydrocarbon oils using synthetic surfactants, but being toxic thus may also cause secondary environmental issues. Thereby, researchers are trying to explore alternative surfactants that may not only be nontoxic and biodegradable but also effective under both mild and severe conditions (Paniagua-Michel and Rosales, 2015). The biosurfactants, employed during bioremediation, would emulsify the hydrophobic substances (like motor oil) in the aqueous systems making them more available as the carbon source for the oildegrading microbes (Vijayakumar and Saravanan, 2015; Duan et al., 2015; Trellu et al., 2016). The microbes detoxify the hydrocarbon pollutants through different modes including polymerization, transformation, or mineralization. Although sole bacterial strain may be enough to remediate the hydrocarbons yet at times bacterial consortia are used for more effective bioremediation. Mostly, Pseudomonads had been reported as exceptional biosurfactant producing species, nevertheless, they exhibit opportunistic human pathogenicity (Khubaib et al., 2021). In that way, it is inevitable to introduce some non-Pseudomonad especially, non-pathogenic bacterial species as a source for biosurfactant-producing strains to remediate the crude oil contaminated systems. For instance, Bacillus species had been reported as lipopeptide producers (Rita de Cássia et al., 2021) whereas Staphylococcus species being a lipopeptide producer with double bonds in its fatty acid chains (Varadavenkatesan and Murty, 2013).

The present study is aimed to isolate and identify some novel non-Pseudomonad non-pathogenic biosurfactant producing bacterial species from the local oil-contaminated soil specimens and use them for the biodegradation of motor oil in the aqueous media under certain physiological and environmental conditions.

\section{Material and methods}

\section{Materials}

Luria Bertani (LB) agar and agar were purchased from Hi-Media (Mumbai, India), cetyltrimethylammonium bromide (CTAB), and methylene from Merck (NJ, USA), ammonium nitrate $\left(\mathrm{NH}_{4} \mathrm{NO}_{3}\right)$, potassium dihydrogen phosphate $\left(\mathrm{KH}_{2} \mathrm{PO}_{4}\right)$, dipotassium hydrogen phosphate $\left(\mathrm{K}_{2} \mathrm{HPO}_{4}\right)$, calcium chloride $\left(\mathrm{CaCl}_{2}\right)$, magnesium sulfate $\left(\mathrm{MgSO}_{4}\right)$, ferric chloride $\left(\mathrm{FeCl}_{3}\right)$, sodium dodecyl sulfate (SDS), potassium chromate $\left(\mathrm{K}_{2} \mathrm{CrO}_{4}\right), 2,6$ 
dichlorophenol indophenol (DCPIP) and heavy metal salts of lead sulfate $\left(\mathrm{PbSO}_{4}\right)$, zinc sulfate $\left(\mathrm{ZnSO}_{4}\right)$, cobalt chloride $\left(\mathrm{CoCl}_{2}\right)$, manganese sulfate $\left(\mathrm{MnSO}_{4}\right)$ and nickel sulfate $\left(\mathrm{NiSO}_{4}\right)$ from Sigma (Missouri, USA) and petrol (Premium Unleaded) from the local market. The antibiotic discs of Ampicillin, Streptomycin, Tetracycline, Erythromycin, and Kanamycine were purchased from Biolab Pharma, Islamabad, Pakistan.

\section{Specimens' collection}

Motor oil-contaminated soil specimens (as 10-100 g) were collected from the three different points of three local auto workshops of Lahore, Pakistan. The specimens were noted for temperature and $\mathrm{pH}$ values and transferred to the laboratory under sterile conditions for working.

\section{Isolation of test bacterial strains}

A desirable amount of soil sample was dispersed in sterilized normal saline serial diluted up to $10^{-6}$ spread on LB agar plate prepared in triplicate and placed in an incubator at $37^{\circ} \mathrm{C}$ overnight. The next day, 20 different bacterial strains were indicated, four out of which were shortlisted based on different screening tests (CTAB/methylene blue-agar, drop collapse, and emulsification assays) as described in the following text.

\section{CTAB/methylene blue-agar assay}

The blue agar plates were prepared as (g/l): 15, 0.2, and 0.005 for agar, CTAB, and methylene blue, in distilled water. The plates were engraved with tiny, cavities and filled with the separate cell cultures of the selected strains and incubated at $37^{\circ} \mathrm{C}$ for $24 \mathrm{~h}$ to identify any production of extracellular glycolipid. The presence of blue halos around the bacterial colonies indicated the production of biosurfactants (Siegmund and Wagner, 1991).

\section{Drop collapse assay}

This technique was employed to screen the biosurfactant-producing strains out of the bacterial strains in hand (Batista et al., 2006). The test bacterial culture was inoculated into LB broth media and further incubated at $37^{\circ} \mathrm{C}$ overnight. Later the centrifugation was performed at $4^{\circ} \mathrm{C}$ and $14,000 \mathrm{rpm}$ for $5 \mathrm{~min}$ to get the supernatant. A $10 \mu \mathrm{l}$ of supernatant was put on a Petri plate and a drop of motor oil was placed over it followed by a few minutes of equilibration. If the drop is collapsed, it indicates that the bacterial strain has secreted some surface-active molecules in the culture media. The procedure was repeated with distilled water as a control.

\section{Emulsification index}

In this test, an aliquot of $2 \mathrm{ml}$ of petrol and an equal amount of supernatant was added in screw-capped test tubes and vortexed vigorously for $2 \mathrm{~min}$. The emulsion hence produced was allowed to settle at $25^{\circ} \mathrm{C}$ for $24 \mathrm{~h}$. Then the height of the emulsification column was measured and put into $E q$. (1) to find out the emulsification index $\left(\mathrm{E}_{24}\right)$ (Cooper and Goldenberg, 1987).

$$
\mathrm{E}_{24}=\frac{\text { Height of emulsion formed }}{\text { Total height of liquids column }} \times 100
$$




\section{Surface tension measurement}

The surface tension changes of the cell-free culture broth were measured using a digital tensiometer (Krüss K10T) calibrated against distilled water $(\sim 2 \mathrm{mN} / \mathrm{m})$.

\section{Identification of the bacterial strains}

Once selected, the bacterial strains were undergone biochemical assays using QTS 24 kit following the standard protocols. The resultant biosurfactant-producing bacterial strains (coded as F1, F9, SJ20, and SJ32) were then analyzed for 16S rRNA gene sequencing.

\section{FTIR analysis}

Fourier transform infrared (FTIR) spectroscopy is widely employed for rapid identification of surface chemistry of bacterial strains and their metabolites containing any lipids, proteins, glycopeptides, polyphosphates, polysaccharides, teichoic acid contents, and so on (Nandiyanto et al., 2019). In the present study, we used the FTIRattenuated total reflection (ATR) technique for the surface characterization of bacterial cell biomass and a representative isolated biosurfactant.

\section{Fermentation setups}

The biosurfactant producing strains were separately inoculated in Bushnell-Hass media containing the components $\left(\mathrm{g} \mathrm{L}^{-1}\right)$ as reported elsewhere (Vandenbergh and Gonzalez, 1984): $\mathrm{KH}_{2} \mathrm{PO}_{4}$ (1.0), $\mathrm{K}_{2} \mathrm{HPO}_{4}$ (1.0), $\mathrm{CaCl}_{2}$ (0.02), $\mathrm{NH}_{4} \mathrm{NO}_{3}$ (1.0), $\mathrm{MgSO}_{4}$ $(0.2)$, and $\mathrm{FeCl}_{3}(0.05)$. The $\mathrm{pH}$ of the minimal media was set (at 6,7 , or 8 ) and autoclaved, accordingly. Then the desirable amount of autoclaved motor oil (as 1, 1.5, 2, 2.5 , or $3 \%, \mathrm{w} / \mathrm{v}$ ) was added as the sole carbon source into the minimal media and incubated on an orbital shaker at a desirable temperature (of 32,37 , or $42^{\circ} \mathrm{C}$ ) and $200 \mathrm{rpm}$ for a desirable period (as 24, 48, 72 or $96 \mathrm{~h}$ ) in the absence or presence of certain inhibitors including SDS and $\mathrm{Cr}(\mathrm{VI})$ ions. All the experiments and analyses were performed in triplicates and their respective analyses were done thrice for concordant data sets. The results are reported as averages on all respective values with standard deviation (SD).

\section{Motor oil biodegradation assay}

The motor oil degradation behavior of the test biosurfactant-producing strains was investigated by adding 2,6 dichlorophenolindophenol (DCPIP: as 1\% w/v, $10 \mu \mathrm{l}$ ) as a redox indicator in the respective culture media on the orbital shaker at $200 \mathrm{rpm}, 37^{\circ} \mathrm{C}$ for $120 \mathrm{~h}$ and after the incubation period, the culture was centrifuged at $1,000 \mathrm{rpm}$ and $4^{\circ} \mathrm{C}$ for $15 \mathrm{~min}$. Any changes in the color of DCPIP were observed by measuring its optical density on a UV-visible spectrophotometer at $750 \mathrm{~nm}$. The oil degradation was indicated by a change in color of the cell-free culture broth.

\section{Heavy metal resistance profile}

A modified version of the method reported elsewhere was used for determining the heavy metal resistance profile of the test bacterial strains (Miranda and Castillo, 1998). The bacterial tolerances to 5 heavy metals, i.e., lead $\left(\mathrm{Pb}^{2+}\right.$ as $\left.\mathrm{PbSO}_{4}\right)$, zinc $\left(\mathrm{Zn}^{2+}\right.$ as $\mathrm{ZnSO}$ ), cobalt $\left(\mathrm{Co}^{2+}\right.$ as $\left.\mathrm{CoCl}_{2}\right)$, manganese $\left(\mathrm{Mn}^{2+}\right.$ as $\left.\mathrm{MnSO}_{4}\right)$, and nickel $\left(\mathrm{Ni}^{2+}\right.$ as $\left.\mathrm{NiSO}_{4}\right)$ were measured on the LB agar plates provided with heavy metal ions (100 to 
$\left.40,000 \mu \mathrm{g} \mathrm{mL}^{-1}\right)$. Then, overnight bacterial cultures were streaked onto the prepared LB agar plates and incubated for $24 \mathrm{~h}$ at $37^{\circ} \mathrm{C}$. The bacteria exhibiting resistance above $500 \mu \mathrm{g} \mathrm{mL}^{-1}$ were tested against higher concentrations to achieve maximum resistance against the above-mentioned metals.

\section{Antibiotic resistance profile}

The test bacterial strains were investigated for antibiotic resistance against some model drugs (at $20 \mu \mathrm{g} \mathrm{ml}^{-1}$ ) including Ampicillin, Streptomycin, Tetracycline, Erythromycin, and Kanamycine on the LB agar media. Fresh bacterial strains were spread on LB agar plates and the above-mentioned antibiotic discs were placed on media with the help of sterilized forceps. The above-mentioned antibiotics discs were placed on the LB agar plates and incubated at $37^{\circ} \mathrm{C}$ for $24 \mathrm{~h}$. Then the zone of inhibition was observed for determining the antibiotic resistance of selected bacterial strains. The width of the clear zone was determined using the $E q$. (2):

$$
\text { Width of clear zone, } \mathrm{mm}=\left[\frac{\text { Dia. of test specimen plus clear zone, } \mathrm{mm}}{\text { Dia. of the specimen, } \mathrm{mm}}\right] \div 2
$$

\section{Statistical analysis}

Analysis of variance (ANOVA) was used for statistical analysis of the experimental data. The $p$-value usually indicates if a factor were either significant $(<0.05)$ or insignificant (>0.05). The F-value indicates if the ratio of variances of two data sets were significantly different.

\section{Extraction and quantification of biosurfactants}

The biosurfactants were extracted from the CFCB of the culture media using the solvent extraction method. Briefly, an aliquot of $200 \mathrm{ml}$ of CFCB mixed with twice equal volumes of ethyl acetate in a separating funnel. The aqueous layer was discarded whereas the organic layer was removed on a rotary evaporator till a brownish residue was obtained which was redissolved in methanol and filtered. The filtrate was recondensed on the rotary evaporator to collect the product (Carrillo et al., 1996).

\section{Results and discussion}

The contaminated soil in the vicinity of workshops contains a high proportion of used or spilled off motor oil where the oil-degrading bacteria naturally reach. The oil and water phases being immiscible need a dispersant for making them miscible at the oil-water interface. Herein, it might be some bacterial secretions behaving as surface-active agents (biosurfactants) which disperse the oily phase into the aqueous media thus making it accessible for bacterial uptake and degradation (Zhao et al., 2015; Gao, 2018). The biosurfactants find extensive applications in various fields of science and technology due to their surface-active and emulsification properties even under extreme conditions (Dhote et al., 2018).

\section{Isolation and characterization of strains}

There observed 20 distinct bacterial strains from the oil-contaminated soil samples (Table S1). The isolates were undergone for emulsification indices and morphological 
and biochemical analyses. The $\mathrm{CTAB} /$ methylene blue agar assay was done, being a semiquantitative assay for the identification of anionic surfactants and any extracellular glycolipids in the vicinity of secreting microbes. The appearance of dark blue halos indicated the secretion of glycolipid biosurfactants (Fig. 1a). The separate cell-free supernatants of the selected strains were undergone a drop collapse assay on a glass surface (Fig. 1b). The supernatants containing any surface-active inclusions collapsed the droplet of motor oil whereas the motor oil droplet remained intact in beaded shapes when it was placed over the control sample or a supernatant not containing any surface-active secretions. Based on the above results, four distinct bacterial strains (designated as F1, F9, SJ20, and SJ32) were indicated as biosurfactants producers which were used for the ongoing study.
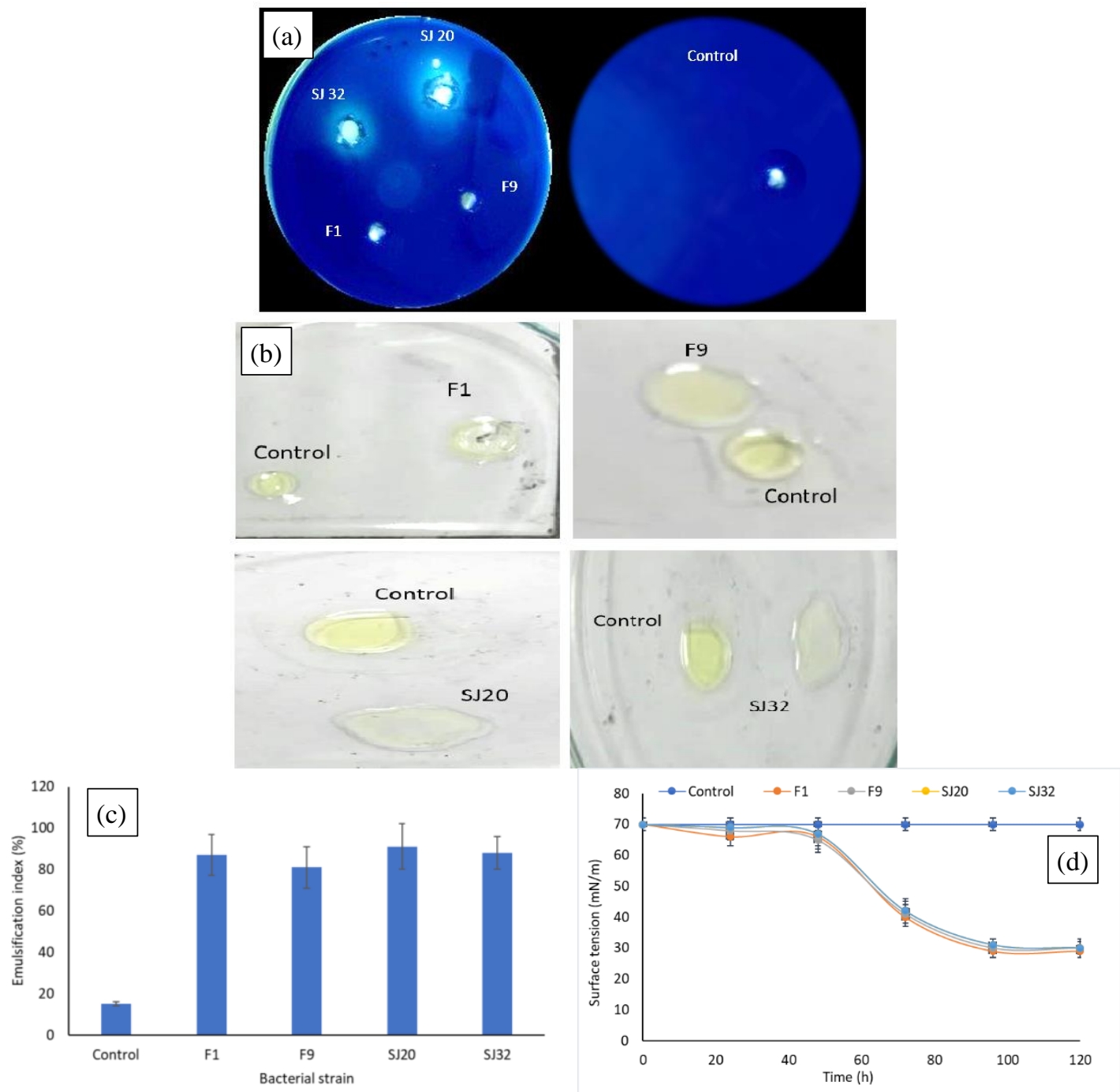

Figure 1. (a) CTAB/methylene blue-agar assay of selected bacterial strains and the control, $(b)$ drop collapse test results selected of bacterial strains and the control, (c) emulsification index of cell-free culture broth of selected bacterial strains and the control against petrol, and (d) surface tension profiles of respective cell-free culture broths; bar $=S D$ 
The selected bacterial strains of F1, F9, SJ20, and SJ32 exhibited the emulsification indices of $87 \pm 10,81 \pm 10,91 \pm 11$, and $88 \pm 8 \%$, respectively against petrol (Fig. 1c). The results indicated that the selected bacterial strains exhibited the ability to extracellularly secrete some surface-active metabolites (may be biosurfactants) into the culture media. The results were further confirmed by measuring surface tension changes of the cell-free culture broths of the respective bacterial strains. The biosurfactants due to extracellular secretions reduced the surface tension of minimal media from $\sim 70 \pm 2 \mathrm{mN} / \mathrm{m}$ to below $30 \pm 1 \mathrm{mN} / \mathrm{m}$ (Fig. 1d).

The selected extracellular surface-active metabolites producing strains then undergone biochemical characterization (Table S1). The strains F1 and F9 showed positive results against catalase, mannitol salt agar, methyl red, and motility tests while negative results against other mentioned biochemical tests. However, the strains SJ20 and SJ32 exhibited positive results against catalase, oxidase, and mobility tests. Eventually, the results demonstrated that the bacterial strains of F1and F9 were Gram-positive cocci whereas the SJ20 and SJ32 strains as the Gram +ve bacilli.

The phylogenetic analysis of four selected bacterial strains was carried out and the resultant 16S rRNA sequences were sent to the GenBank for assigning the accession numbers as MT107124, MT107125, MT103051, and MT103052 for the selected isolates of F1, F9, SJ20, and SJ32, respectively (Fig. S1). The BLAST analysis indicated that F1 and F9 isolates expressed 99\% homology to the genera Staphylococcus, whereas SJ20 and SJ32 isolates showed homology with the genera Bacillus (Fig. S2). Hence, the selected isolates of F1, F9, SJ20, and SJ32 were identified as Staphylococcus hominis, Staphylococcus sp., Bacillus flexus, and Bacillus oceanisediminus, respectively, being of non-Pseudomonad origin. The results reported in this study have been supported by the literature (Kumar et al., 2018).

\section{FTIR analysis of bacterial surfaces}

The FTIR analysis of cell surface of Staphylococcus hominis F1 expressed a sharp peak at $3301 \mathrm{~cm}^{-1}$ for $\mathrm{C}-\mathrm{H}$ and $\mathrm{H}-\mathrm{N}$ stretching vibrations, the latter indicated the presence of amino group (Fig. 2a). The peaks at 2919 and $2874 \mathrm{~cm}^{-1}$ indicated the presence of $\mathrm{CH}_{2}$-and $-\mathrm{CH}_{3}$ moieties, respectively. There observed a peak at $1637 \mathrm{~cm}^{-1}$ designated for the CO-N stretching. The peaks at 1457, 1244, and $1111 \mathrm{~cm}^{-1}$ expressed C-H, C-O-C (ester), and C-O stretching vibrations, respectively. The FTIR spectrum of the cell surface of Staphylococcus sp F9 (Fig. 2b) indicated a peak at $3243 \mathrm{~cm}^{-1}$ for N-H bond, and two more peaks at 2966 and $2863 \mathrm{~cm}^{-1}$ for asymmetric stretching of $-\mathrm{CH}_{3}$ and $-\mathrm{CH}_{2}$ - moieties, respectively. Two peaks at 1747 and $1686 \mathrm{~cm}^{-1}$ indicated $\mathrm{C}=\mathrm{O}$ stretching vibrations. The peaks at 1652,1557 , and $1264 \mathrm{~cm}^{-1}$ corresponded to the presence of peptide bond, N-H deformation, and C-N stretching, respectively. The FTIR spectrum of the cell surface of Bacillus flexus (SJ20) (Fig. 2c) expressed a sharp peak at $3413 \mathrm{~cm}^{-1}$ corresponded to the $\mathrm{N}-\mathrm{H}$ stretching vibration of the amino group. A peak at $1650 \mathrm{~cm}^{-1}$ indicated $-\mathrm{CO}-\mathrm{N}$ stretching vibration which might be due to some lipopeptide secretions on the cell surface (Kanmani et al., 2017). The peaks at 2924 and $2880 \mathrm{~cm}^{-1}$ indicated symmetric and asymmetric stretching of $\mathrm{C}-\mathrm{H}$, respectively. A peak at $1101 \mathrm{~cm}^{-1}$ could be due to the $\mathrm{C}$ $\mathrm{O}-\mathrm{C}$ stretching vibration belonging to the ester moieties. The FTIR spectrum of Bacillus oceanisediminis (SJ32) (Fig. 2d) expressed peaks at 2860 and $2960 \mathrm{~cm}^{-1}$ indicating the presence of $-\mathrm{CH}_{2}$ - and $-\mathrm{CH}_{3}$ bonds while that in the range $2800-3400 \mathrm{~cm}^{-1}$ indicated the presence of $\mathrm{OH}$ stretching. The sharp peak at $1735 \mathrm{~cm}^{-1}$ showed the presence of ester linkage. The peaks at $1456 \mathrm{~cm}^{-1}$ and $1348 \mathrm{~cm}^{-1}$ indicated bending vibrations of $-\mathrm{CH}_{2}$ - and 
$-\mathrm{CH}_{3}$ moieties while that at $3381 \mathrm{~cm}^{-1}$ indicated the presence of $\mathrm{N}-\mathrm{H} / \mathrm{C}-\mathrm{H}$ bonds. A peak at $1559 \mathrm{~cm}^{-1}$ indicated the presence of $\mathrm{N}-\mathrm{H}$ bending vibration.

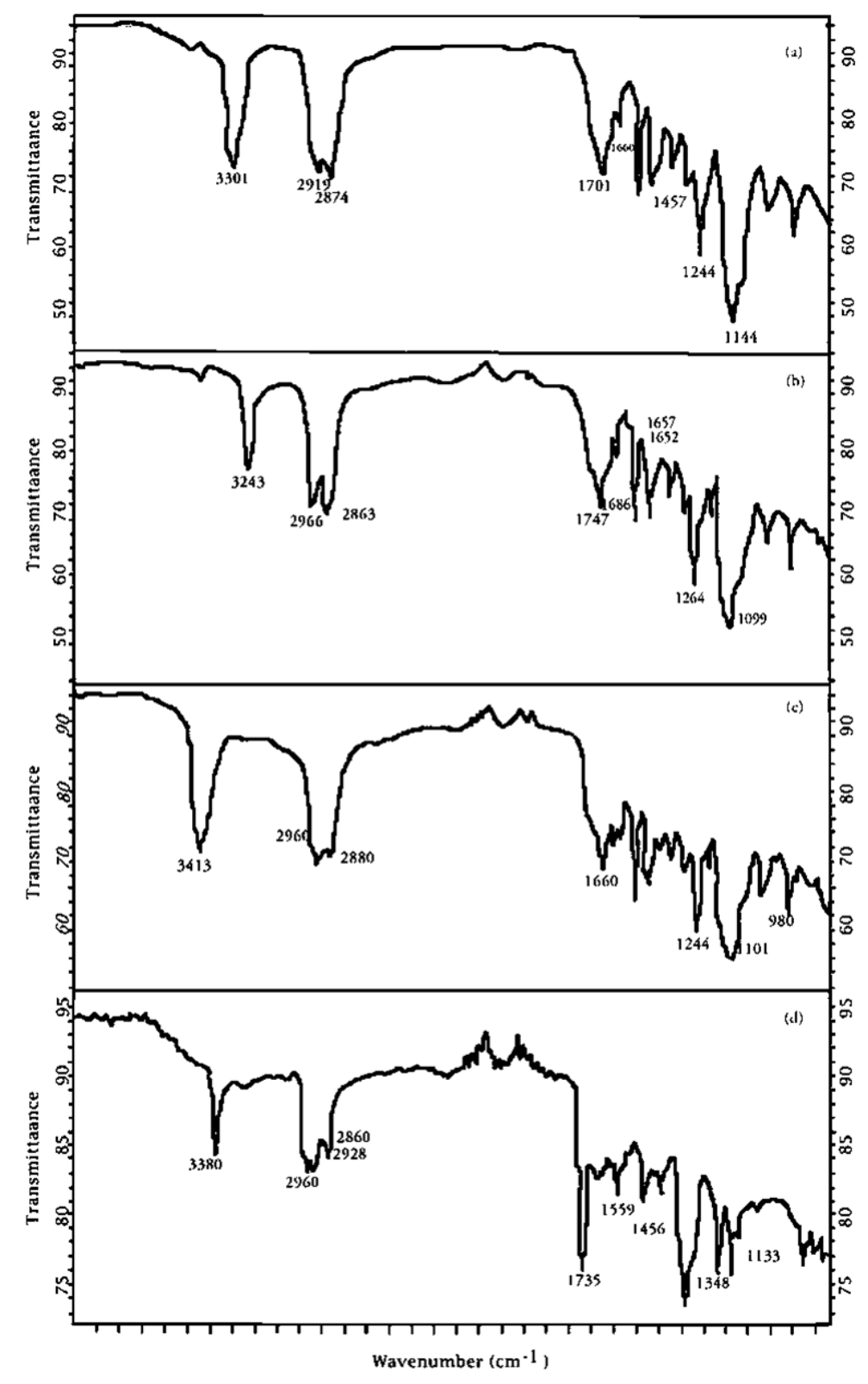

Figure 2. FTIR spectra of cell surfaces of (a) Staphylococcus hominis F1, (b) Staphylococcus sp. F9, (c) Bacillus flexus SJ20, and (d) Bacillus oceanisediminis SJ32. (The transmittance has been reported in percent)

\section{Antibiotic resistance profile}

The biosurfactant producing bacterial isolates were also tested for resistance against different commonly used antibiotics (as $20 \mu \mathrm{g} \mathrm{mL} \mathrm{m}^{-1}$ ) as shown in Fig. 3 and the respective data is expressed in Table S2. The selected bacterial isolates were found to be resistant against Ampicillin, Streptomycin, Tetracycline, Erythromycin, and Kanamycine, while one isolate i.e., Bacillus oceanisediminis expressed sensitivity towards Kanamycin. 


\section{Metal resistance test}

The results demonstrated that most of the selected biosurfactant-producing strains showed resistance against the heavy metals of lead $(\mathrm{Pb})$ and manganese $(\mathrm{Mn})$. The least resistance was observed against $\mathrm{Zn}^{+2}$ followed by $\mathrm{Co}^{+2}$, and $\mathrm{Ni}^{+2}$ ions with all bacterial isolates (Table S2). In general, the heavy metal resistance profile of all the biosurfactantproducing strains was as follows: $\mathrm{Pb}^{+2}>\mathrm{Mn}^{+2}>\mathrm{Ni}^{+2}>\mathrm{Co}^{+2}>\mathrm{Zn}^{+2}$. Heavy metals are regarded as one of the influential parameters that play a significant role not only in bacterial growth but also in their degradation behavior. For determining the potential of bacterial strains to resist heavy metals, the cross-metal resistance of bacterial strains was determined. This is helpful especially concerning heavy metals bioremediation because bacteria can behave more effectively if they can grow in the presence of toxic heavy metals.
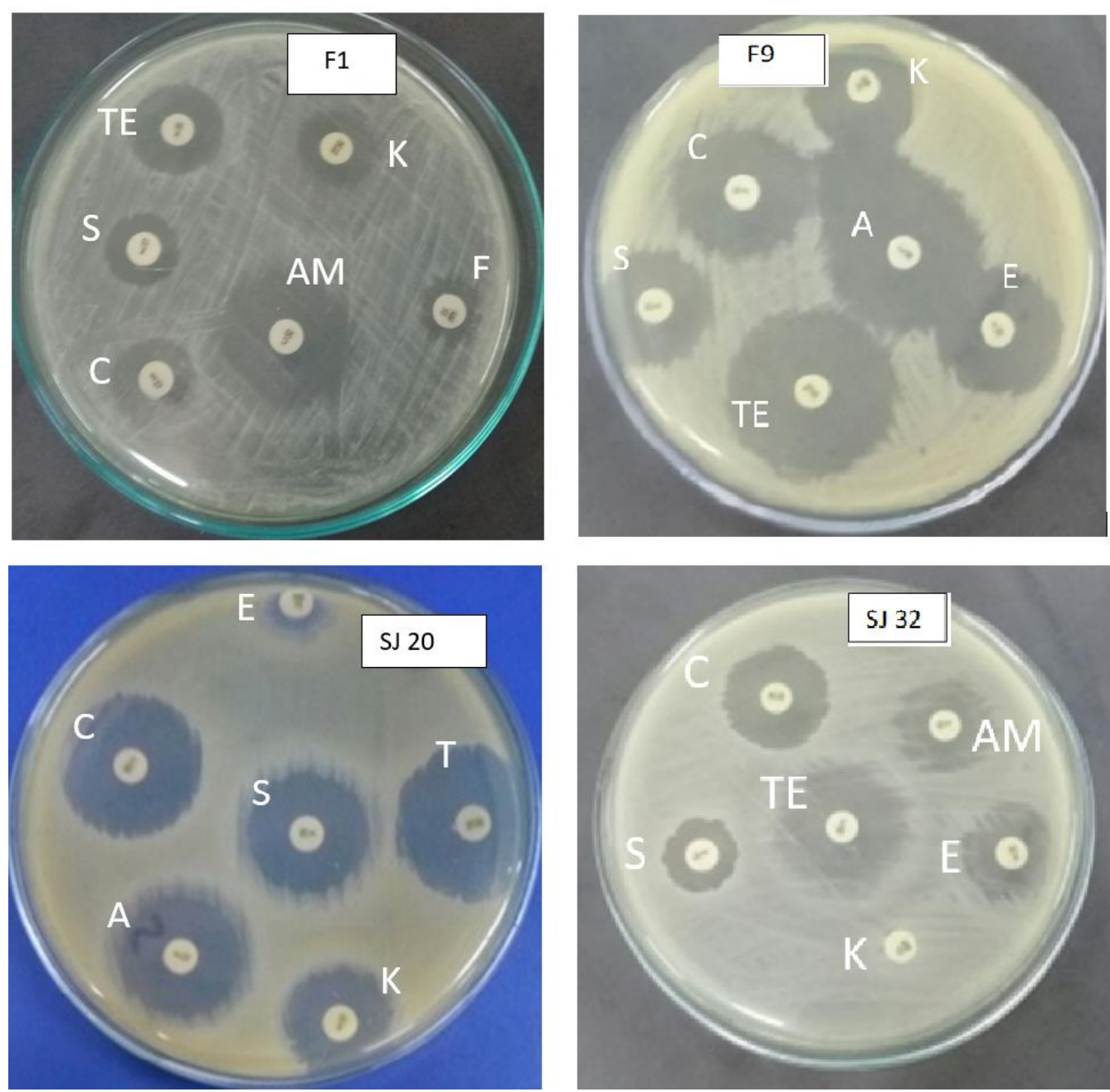

Figure 3. Antibiotic resistance profile of selected bacterial strains (as per labeled F1(Staphylococcus hominis), F9 (Staphylococcus sp.), SJ20 (Bacillus flexus), and SJ32 (Bacillus oceanisediminis) against the drugs (as $20 \mu \mathrm{g} / \mathrm{mL}$ ) of streptomycin (S), ampicillin $(A M)$, tetracycline $(T)$, kanamycin $(K)$, erythromycin $(E)$, and chloramphenicol $(C)$ 


\section{Motor oil biodegradation study}

\section{Effect of initial motor oil concentration}

The effect of different concentrations of motor oil (1-3\%, w/v) on the degradation behavior in the minimal media has been investigated using the DCPIP assay. The bacterial degradation of the motor oil was observed as the reduced color intensity of 2,6 DCPIP in comparison to the control. The DCPIP, being an electron acceptor, ensures the capability of the test bacterial strain in utilizing the hydrocarbon substrate; as on biodegradation, the change of DCPIP color from blue to colorless shows the change from oxidized state to the reduced state. Thereby, all the selected bacterial strains possessed the capability to use motor oil as the sole carbon source, though to different extents, under certain fermentative conditions (Fig. 4). The trend of percent removal of motor oil decreased on increasing the respective initial concentration of motor oil. On increasing the carbon source of the minimal media, a decrease in percent carbon source utilization had also been reported in the literature (El-Sayed et al., 1995; Bayat et al., 2015). This might be due to excessive carbon contents in the minimal media which might imbalance the $\mathrm{C} / \mathrm{N}$ ratio, in that case. The highest percent removal of motor oil could be observed with the Staphylococcus sp. at $1 \%(\mathrm{w} / \mathrm{w})$ motor oil at $37^{\circ} \mathrm{C}, \mathrm{pH} 7,200 \mathrm{rpm}$ after $96 \mathrm{~h}$ of incubation. In general, the lowest percent motor oil removal was observed at 3\% (w/w) initial oil concentration. This might be due to the excess availability of carbon contents in the culture media which might form a miscible layer on the aqueous minimal media, particularly in the early days of incubation. However, after a certain time interval, enough biosurfactant contents could be secreted into the culture media thus enabling both phases to miscible into each other which facilitates the motor oil degradation. In an earlier study, the maximum hydrocarbon utilization of up to $73.97 \%(\mathrm{w} / \mathrm{w})$ was achieved by the bacterial cultures with $1 \%(\mathrm{v} / \mathrm{v}) n$-hexadecane as the sole carbon source. On increasing the $n$-hexadecane concentration to 2 and then to $3 \%(\mathrm{v} / \mathrm{v})$, the oil degradation was limited to 61.90 and $47.33 \%$ (w/w), respectively (Cameotra and Singh, 2009). The carbon source contents above a certain limit also hider the bacterial growth hence the oil degradation too (Abid et al., 2016).

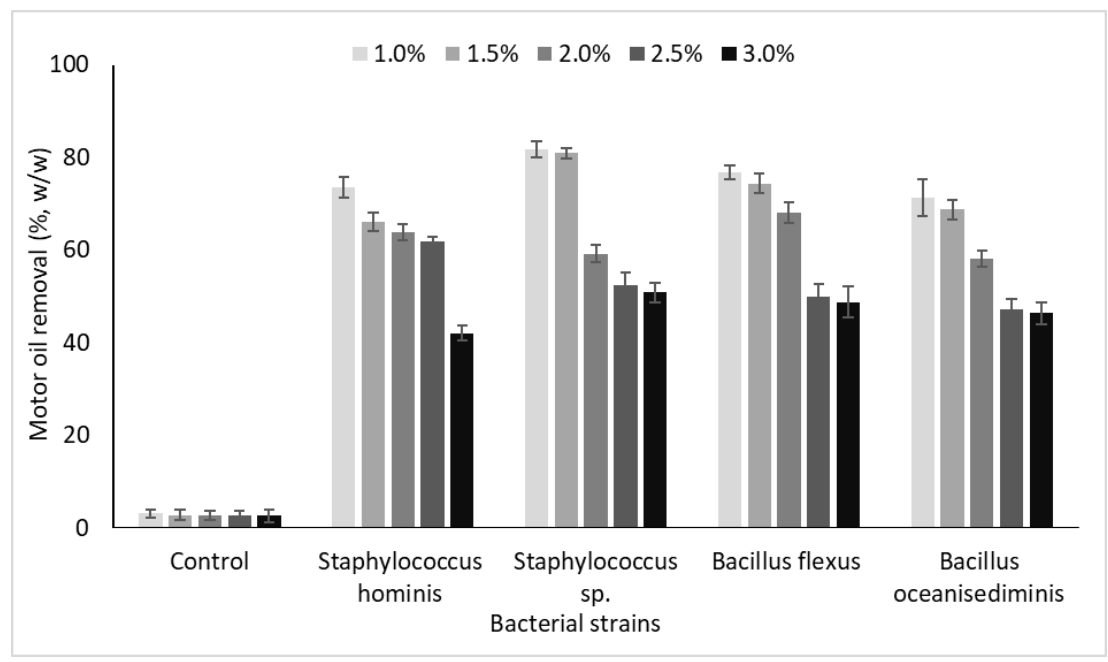

Figure 4. Effect of motor oil concentration on biodegradation behavior with the selected bacterial strains at $37^{\circ} \mathrm{C}$, $\mathrm{pH}$ at 7, $200 \mathrm{rpm}$ after $96 \mathrm{~h}$ of incubation; control = in media without any bacterial strain, bar $=S D$ 


\section{The combined effect of $\mathrm{pH}$ and motor oil concentration}

The $\mathrm{pH}$ value of the culture media is also an important factor that affects the oil degradation behavior of bacterial strains. Since the extracellular metabolites might fluctuate the $\mathrm{pH}$ of the media so the fermentation was conducted in the phosphate buffer saline at the desirable $\mathrm{pH}$ values (6-8) with the desirable initial motor oil concentrations (being 1-3\%, w/v) (Fig. 5). In general, at either motor oil consideration or with any selected bacterial strain, the highest percent oil removal was observed at $\mathrm{pH} 7$ of the culture media. The highest percent oil removal was observed at $81.8 \%$ (w/w) with $1 \%$ (w/v) motor oil at $\mathrm{pH} 7$ by the bacterial strain of Staphylococcus sp. after $96 \mathrm{~h}$ of incubation at $37^{\circ} \mathrm{C}$ and $200 \mathrm{rpm}$ (Fig. $5 a$ ). The acidic pH, in general, was least favorable for bacterial growth which was reflected by the lowest respective motor oil degradation results. The lowest oil degradation being $9-5 \%(\mathrm{w} / \mathrm{w})$ was observed at $3 \%(\mathrm{w} / \mathrm{w})$ initial oil concentration in the presence of $S$. hominies (Fig. 5e). These results are consistent with the findings of other researchers who found that different bacterial strains showed maximum oil biodegradation at pH 7 (Palanisamy et al., 2014; Sivagamasundari, 2017; Behera et al., 2021).
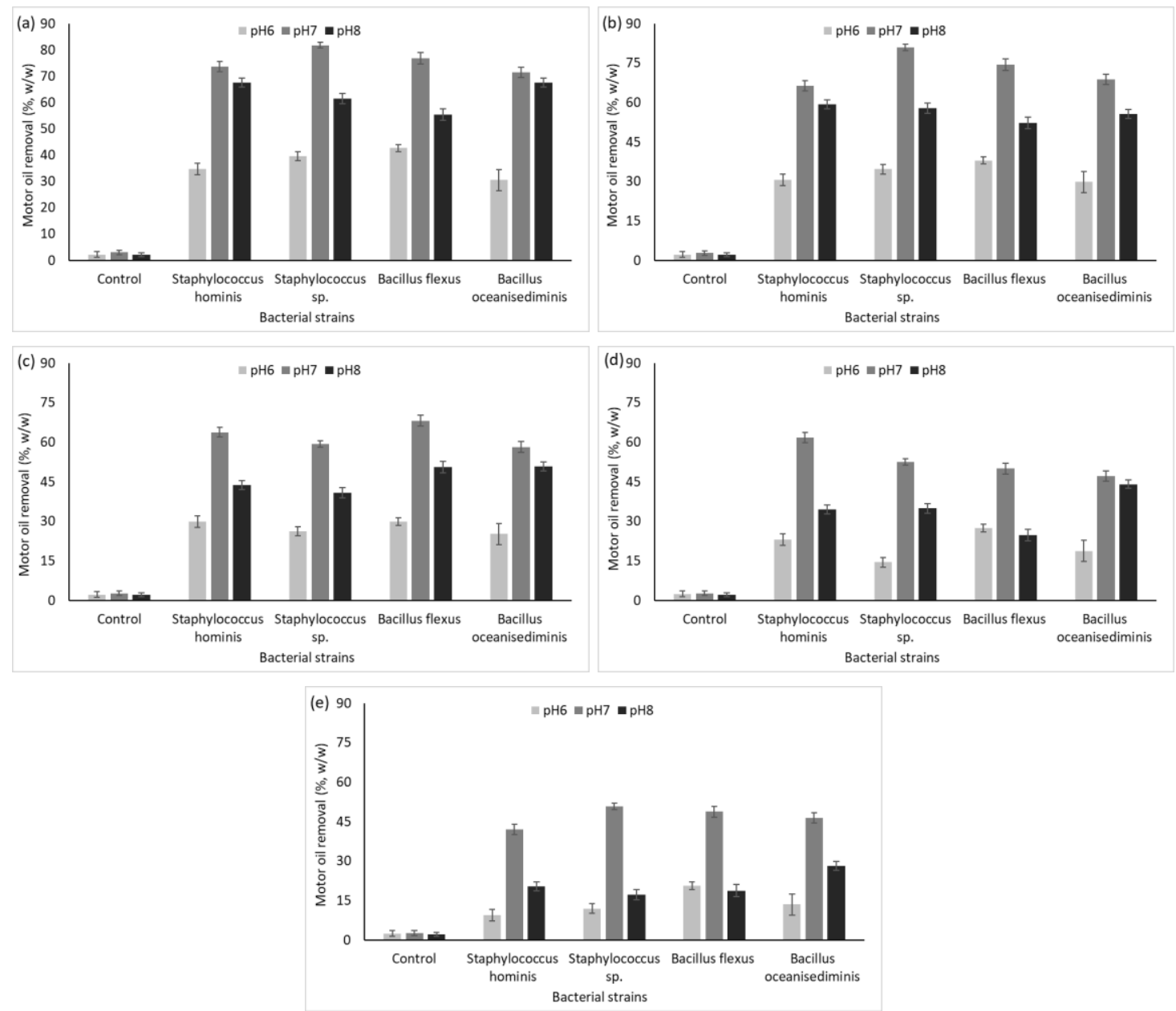

Figure 5. Effect of bacterial strains at different levels of $\mathrm{pH}(6,7$ and 8) and motor oil concentrations $(1.0(a), 1.5(b), 2.0(c), 2.5(d)$ and $3 \%(w / v)(e))$ on degradation profiles at $37^{\circ} \mathrm{C}$ and $200 \mathrm{rpm}$ after $96 \mathrm{~h}$ of incubation (2, 6 Dichlorophenol indophenol assay at $750 \mathrm{~nm}$ ); control $=$ in media without any bacterial strain, bar $=S D$ 


\section{The combined effect of incubation temperature and motor oil concentration}

Once the $\mathrm{pH}$ of the media was optimized to be 7 , the culture media were investigated at various incubation temperatures for all the selected bacterial strains at various initial oil contents (Fig. 6). Any changes in temperature from the optimum value may affect the physicochemical and biogenic attributes of the motor oil as the sole carbon source. The experiments were conducted at 32,37 , or $42^{\circ} \mathrm{C}$. In general, the optimum incubation temperature was observed to be $37^{\circ} \mathrm{C}$ at either initial oil contents with either selected bacterial strain. The highest percent oil removal $(81.8 \%, \mathrm{w} / \mathrm{w})$ was observed at $37^{\circ} \mathrm{C}$ and $1 \%(\mathrm{w} / \mathrm{w})$ initial oil concentration with the bacterial strain of Staphylococcus sp. The incubation temperatures of 32 and $42^{\circ} \mathrm{C}$ were observed to be unfavorable for bacterial growth at either oil concentration. The bacterial strain of Staphylococcus sp. was observed to remove just $1.6 \%(\mathrm{w} / \mathrm{w})$ oil contents at $42^{\circ} \mathrm{C}$ after $96 \mathrm{~h}$ of incubation. These findings coincide with the results of Kao et al. (2005) who reported that the biodegradation rate was the highest at the optimum growth temperature of the mesophilic bacteria that ranged between $25-30^{\circ} \mathrm{C}$ (Bossert and Bartha, 1984; Rahman et al., 2002; Ren et al., 2021).

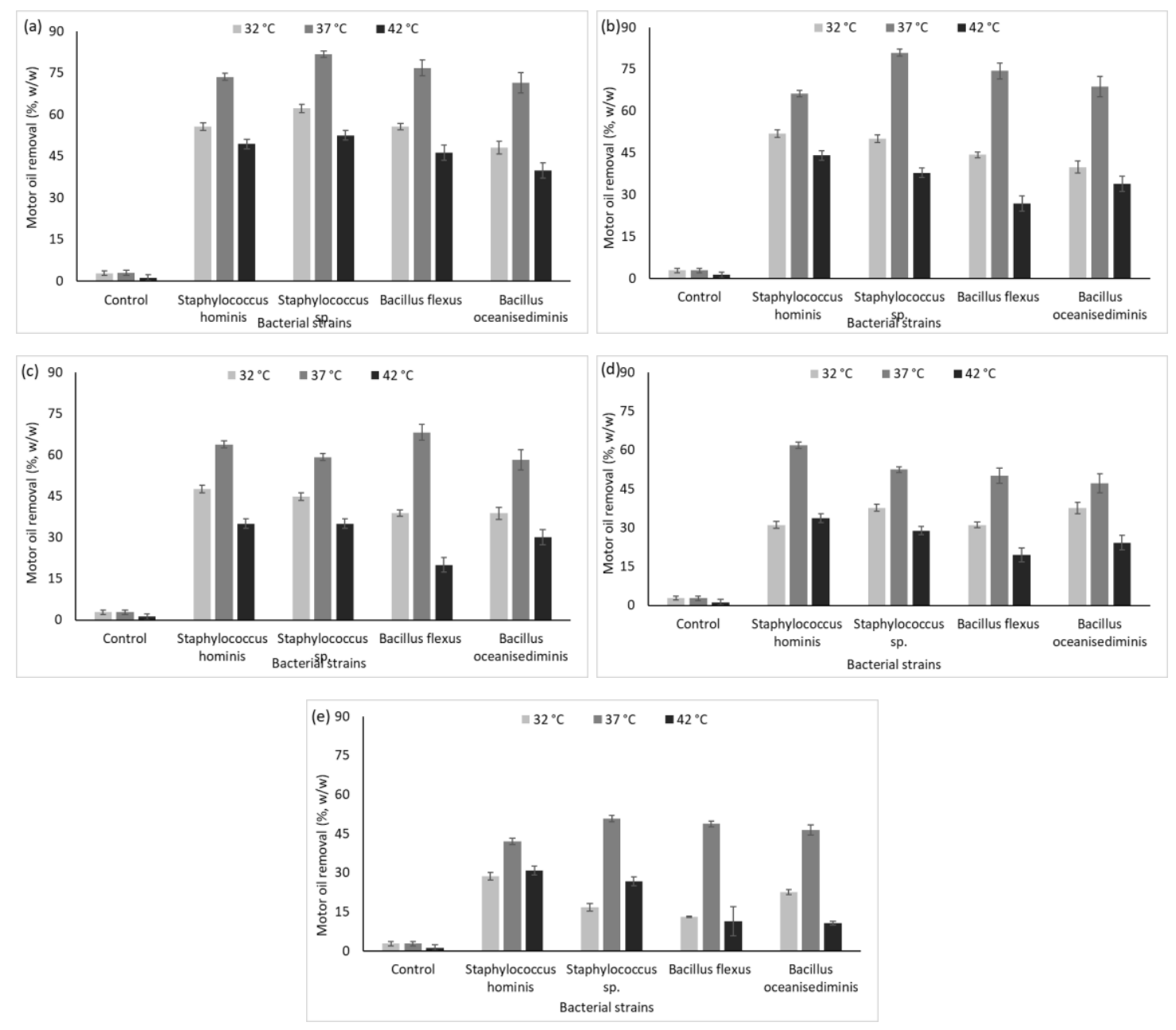

Figure 6. Effect of bacterial strains at different temperatures $\left(32,37\right.$ and $\left.42^{\circ} \mathrm{C}\right)$ and motor oil concentrations $(1.0(a), 1.5(b), 2.0(c), 2.5(d)$ and $3 \%(w / w)(e))$ on degradation profiles at $p H$ 7 and $200 \mathrm{rpm}$ after $96 \mathrm{~h}$ of incubation (2, 6 Dichlorophenol indophenol assay at $750 \mathrm{~nm}$ ); control $=$ in media without any bacterial strain, bar $=S D$ 


\section{The combined effect of incubation time on motor oil concentration}

For determining the impact of incubation time on motor oil biodegradation behavior of selected bacterial strains different incubation times $(24,48,72$, and $96 \mathrm{~h})$ were selected. It can be seen from Figure 7 that as the incubation time was increased the selected bacterial strains showed higher biodegradation of motor oil. It was found that incubation time is directly proportional to the motor oil biodegradation activity of microorganisms (Javed et al., 2015). At 1\% (w/v) motor oil concentration, when the incubation time was increased from 24 to $96 \mathrm{~h}$, the biodegradation rate also increased from 40.0 to $81.8 \%$ (w/w). Similar behavior of motor oil biodegradation was observed with other motor oil concentrations and it was found that motor oil biodegradation was increased with an increase in incubation time. Although with an increase of incubation time, the biodegradation activity was increased, however, it was found that biodegradation activity was slowed time with the increase of incubation time. The previous literature also shows that higher incubation time favors oil biodegradation (John et al., 2021).
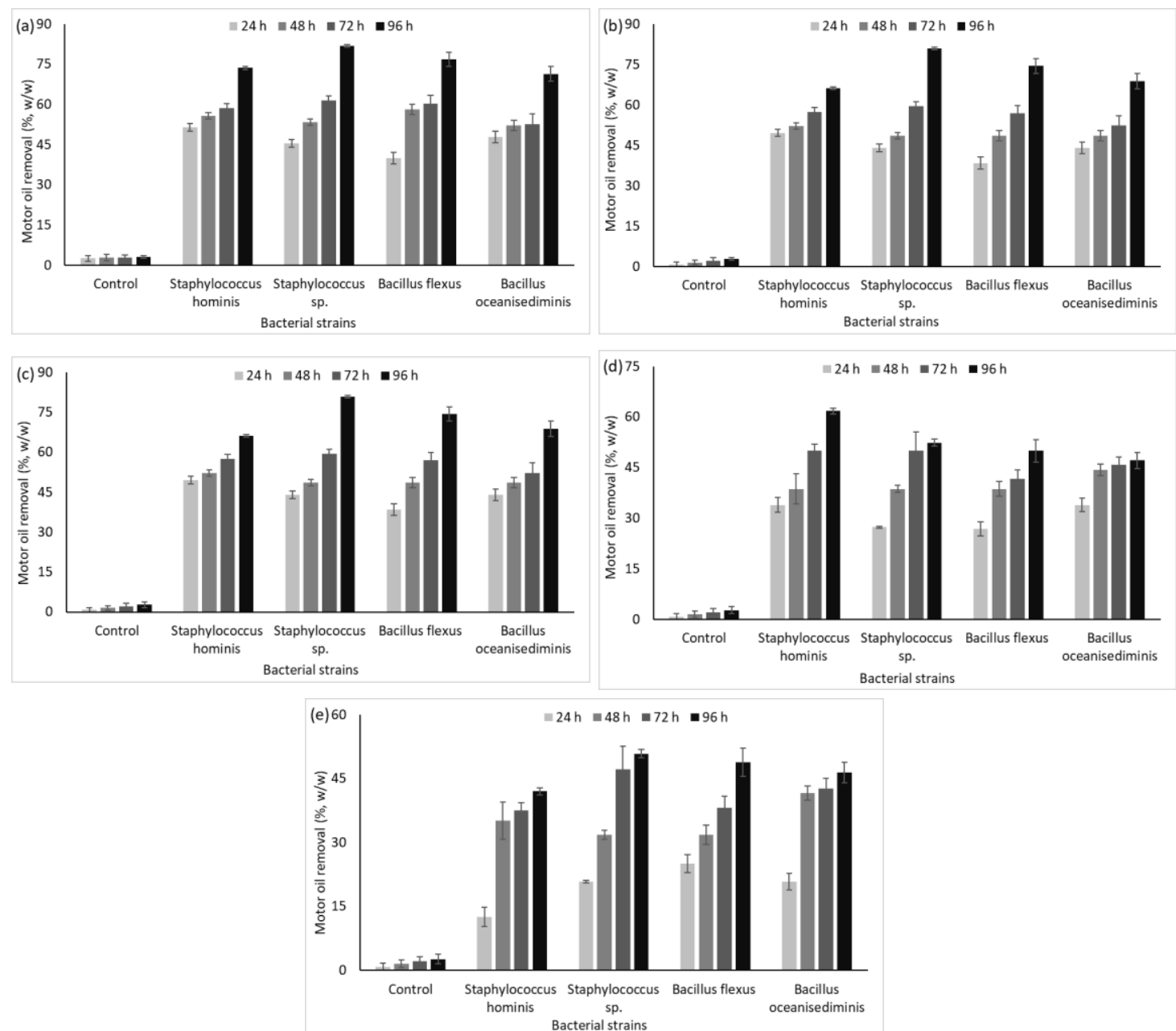

Figure 7. Effect of bacterial strains at different incubation time $(24,48,72$ and $96 \mathrm{~h})$ and motor oil concentrations $(1.0(a), 1.5(b), 2.0(c), 2.5(d)$ and $3 \%(w / v)(e))$ on degradation profiles at $37^{\circ} \mathrm{C}$, pH at 7 and 200 rpm after $96 \mathrm{~h}$ of incubation (2, 6 Dichlorophenol indophenol assay at $750 \mathrm{~nm}) ;$ control = in media without any bacterial strain, bar $=S D$ 


\section{Effect of inhibitors}

The SDS was tested if it could inhibit the growth of biosurfactant-producing bacteria. Two concentrations of SDS (as 1 and $2 \%$, w/v) were tested at different concentrations of motor oil (Fig. 8a,b). At SDS 1\% (w/v), maximum inhibition of 3 to $11 \%$ was observed with 1 and $2 \%(\mathrm{w} / \mathrm{v})$ motor oil concentrations, respectively. On increasing the SDS content to $2 \%(\mathrm{w} / \mathrm{v})$, the inhibition of $0.8 \%$ was observed at $3 \%(\mathrm{w} / \mathrm{v})$ oil concentration, while other test concentrations of motor oil did not exhibit significant inhibition. Heavy metals are also present in the environment in a small proportion; however, their proportion is increasing due to the increase in industrial activities. Heavy metals can either inhibit or increase the biodegradation process. In this study, $\mathrm{Cr}(\mathrm{VI})$ ions were selected for studying the inhibitory effect of heavy metals on the biodegradation process. When $1,000 \mu \mathrm{g} / \mathrm{ml}$ concentration of $\mathrm{Cr}(\mathrm{VI})$ ions was used the maximum inhibition of biodegradation was shown by bacterial strain Staph. hominis at $1 \%(\mathrm{w} / \mathrm{v})$ oil concentration. At a higher concentration of heavy metals, the micro-organisms showed higher inhibition as they instantaneously stop their activities (Javed et al., 2015).
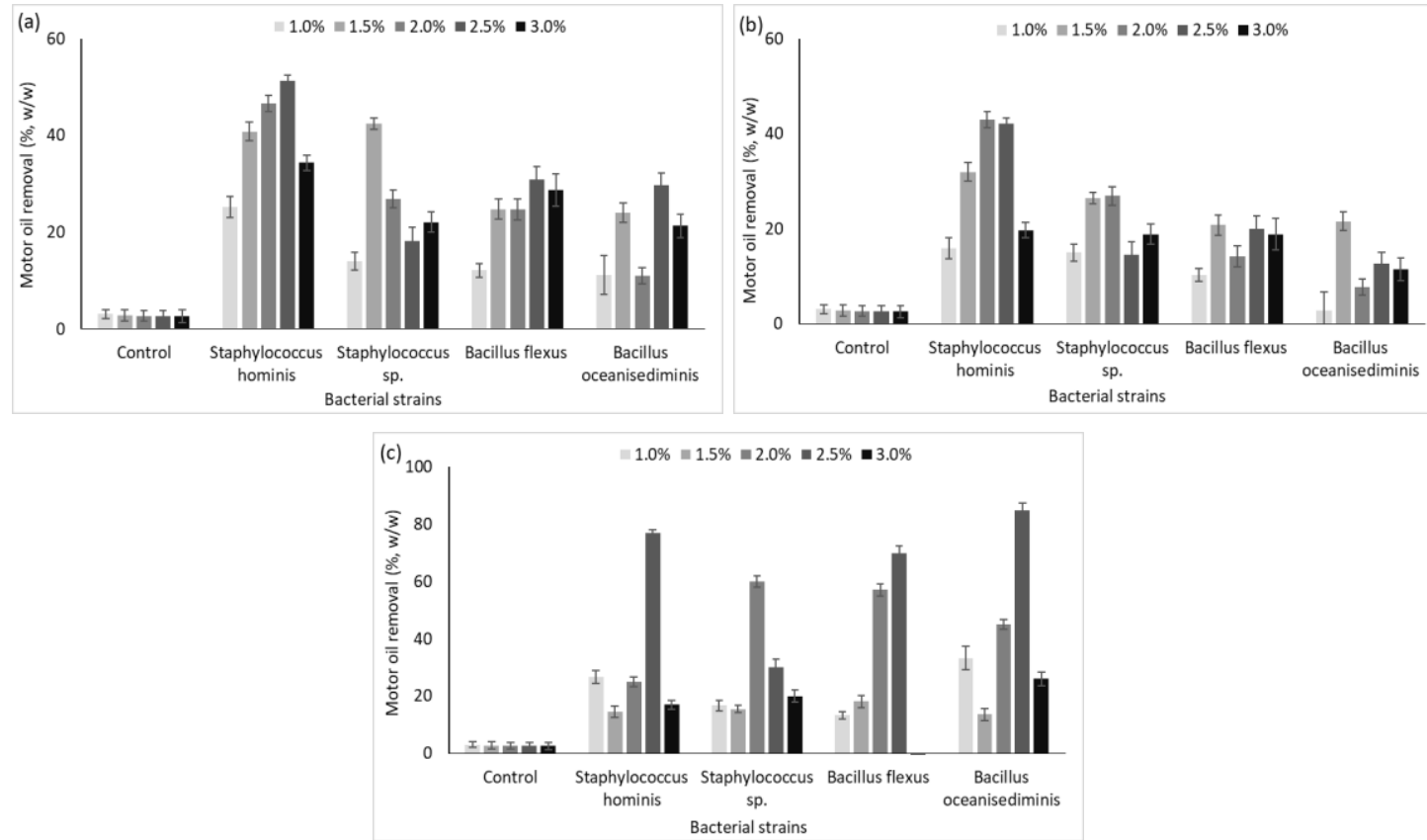

Figure 8. Effect of inhibitors: SDS at $1 \%(a)$ and $2 \%(w / v)(b) w / v$ and chromium $(1,000 \mu \mathrm{g} / \mathrm{ml})$ (c) on the motor oil degradation behavior at different concentrations $(1.0,1.5,2.0,2.5$ and $3 \%$, $w / v)$ by using selected bacterial at $37^{\circ} \mathrm{C}$ and $200 \mathrm{rpm}$ (2, 6 Dichlorophenol indophenol assay at $750 \mathrm{~nm}) ;$ control = in media without any bacterial strain, bar $=S D$

The statistical analysis indicated that the initial oil concentration, $\mathrm{pH}$ value of the culture media, incubation time, and SDS and Cr(IV) ions concentrations were significant factors at either fermentation setup whereas the bacterial strain type was observed to be an insignificant parameter in either case except on changing the SDS concentration in the culture media (Table 1). Since the selected bacterial strains were all capable to degrade the motor oil so the choice of the bacterial strains becomes insignificant in the comparison. However, the prior presence of surfactant (i.e., SDS) in the culture media supports the motor oil degradation in the culture media due to its emulsification behavior. 
Table 1. Effect of multiple factors on the motor oil degradation (\%) under various fermentation setups

\begin{tabular}{|c|c|c|c|c|c|c|}
\hline Setup & Constants & Factors & Hypothesis & F-value & P-value & Remarks \\
\hline \multirow{2}{*}{ I } & \multirow{2}{*}{$\begin{array}{c}\mathrm{pH}=7 \\
\text { Incubation time }=96 \mathrm{~h} \\
\text { Temp. } 37^{\circ} \mathrm{C}\end{array}$} & Bacterial strains & $\begin{array}{c}\mathrm{H}_{\mathrm{o}}: \mu_{1}=\mu_{2}=\mu_{3}=\mu_{4} \\
\mathrm{H}_{1:} \text { at least two means are unequal }\end{array}$ & 1.73 & 0.214 & Insignificant \\
\hline & & Int. oil conc. & $\begin{array}{c}\mathrm{H}_{\mathrm{o}}: \mu_{5}=\mu_{6}=\mu_{7}=\mu_{8}=\mu_{9} \\
\mathrm{H}_{1:} \text { at least two means are unequal }\end{array}$ & 25.25 & 0.00 & Significant \\
\hline \multirow{3}{*}{ II } & \multirow{3}{*}{$\begin{array}{l}\text { Incubation time }=96 \mathrm{~h} \\
\text { Temp. } 37^{\circ} \mathrm{C}\end{array}$} & Bacterial strains & $\begin{array}{c}\mathrm{H}_{\mathrm{o}}: \mu_{1}=\mu_{2}=\mu_{3}=\mu_{4} \\
\mathrm{H}_{1:} \text { at least two means are unequal }\end{array}$ & 0.34 & 0.80 & Insignificant \\
\hline & & Int. oil conc. & $\begin{array}{c}\mathrm{H}_{\mathrm{o}}: \mu_{5}=\mu_{6}=\mu_{7}=\mu_{8}=\mu_{9} \\
\mathrm{H}_{1:} \text { at least two means are unequal }\end{array}$ & 5.01 & 0.002 & Significant \\
\hline & & $\mathrm{pH}$ & $\begin{array}{c}\mathrm{H}_{\mathrm{o}}: \mu_{10}=\mu_{11}=\mu_{12} \\
\mathrm{H}_{1:} \text { at least two means are unequal }\end{array}$ & 20.4 & 0.00 & Significant \\
\hline \multirow{3}{*}{ III } & \multirow{3}{*}{$\begin{array}{c}\mathrm{pH}=7 \\
\text { Incubation time }=96 \mathrm{~h}\end{array}$} & Bacterial strains & $\begin{array}{c}\mathrm{H}_{\mathrm{o}}: \mu_{1}=\mu_{2}=\mu_{3}=\mu_{4} \\
\mathrm{H}_{1:} \text { at least two means are unequal }\end{array}$ & 0.63 & 0.59 & Insignificant \\
\hline & & Int. oil conc. & $\begin{array}{c}\mathrm{H}_{\mathrm{o}}: \mu_{5}=\mu_{6}=\mu_{7}=\mu_{8}=\mu_{9} \\
\mathrm{H}_{1:} \text { at least two means are unequal }\end{array}$ & 7.73 & 0.00 & Significant \\
\hline & & Temperature & $\begin{array}{c}\mathrm{H}_{\mathrm{o}}: \mu_{13}=\mu_{14}=\mu_{15} \\
\mathrm{H}_{1:} \text { at least two means are unequal }\end{array}$ & 32.57 & 0.00 & Significant \\
\hline \multirow{3}{*}{ IV } & \multirow{3}{*}{$\begin{aligned} \mathrm{pH} & =7 \\
\text { Temp. } & =37^{\circ} \mathrm{C}\end{aligned}$} & Bacterial strains & $\begin{array}{c}\mathrm{H}_{\mathrm{o}}: \mu_{1}=\mu_{2}=\mu_{3}=\mu_{4} \\
\mathrm{H}_{1:} \text { at least two means are unequal }\end{array}$ & 0.16 & 0.92 & Insignificant \\
\hline & & Oil conc. & $\begin{array}{c}\mathrm{H}_{\mathrm{o}}: \mu_{5}=\mu_{6}=\mu_{7}=\mu_{8}=\mu_{9} \\
\mathrm{H}_{1: \text { at least two means are unequal }}\end{array}$ & 12.60 & 0.00 & Significant \\
\hline & & Incubation time & $\begin{array}{c}\mathrm{H}_{\mathrm{o}}: \mu_{16}=\mu_{17}=\mu_{18}=\mu_{19} \\
\mathrm{H}_{1:} \text { at least two means are unequal }\end{array}$ & 25.12 & 0.00 & Significant \\
\hline \multirow{3}{*}{$\mathrm{V}$} & \multirow{3}{*}{$\begin{array}{c}\mathrm{pH}=7 \\
\text { Incubation time }=96 \mathrm{~h} \\
\text { Temp. } 37^{\circ} \mathrm{C}\end{array}$} & Bacterial strains & $\begin{array}{c}\mathrm{H}_{\mathrm{o}}: \mu_{1}=\mu_{2}=\mu_{3}=\mu_{4} \\
\mathrm{H}_{1:} \text { at least two means are unequal }\end{array}$ & 2.84 & 0.039 & Significant \\
\hline & & Int. oil conc. & $\begin{array}{c}\mathrm{H}_{\mathrm{o}}: \mu_{5}=\mu_{6}=\mu_{7}=\mu_{8}=\mu_{9} \\
\mathrm{H}_{1:} \text { at least two means are unequal }\end{array}$ & 8.45 & 0.00 & Significant \\
\hline & & SDS & $\begin{array}{c}\mathrm{H}_{\mathrm{o}}: \mu_{20}=\mu_{21} \\
\mathrm{H}_{1:} \text { Two means are unequal }\end{array}$ & 4.40 & 0043 & Significant \\
\hline
\end{tabular}




\begin{tabular}{|c|c|c|c|c|c|c|}
\hline Setup & Constants & Factors & Hypothesis & F-value & P-value & Remarks \\
\hline \multirow{2}{*}{ VI } & \multirow{2}{*}{$\begin{array}{c}\mathrm{pH}=7 \\
\text { Incubation time }=96 \mathrm{~h} \\
\text { Temp. } 37^{\circ} \mathrm{C} \\
\mathrm{Cr}(\mathrm{IV})=1000 \mu \mathrm{g} / \mathrm{ml}\end{array}$} & Bacterial strains & $\begin{array}{c}\mathrm{H}_{\mathrm{o}}: \mu_{1}=\mu_{2}=\mu_{3}=\mu_{4} \\
\mathrm{H}_{1:} \text { at least two means are unequal }\end{array}$ & 0.66 & 0.594 & Insignificant \\
\hline & & Oil concentration & $\begin{array}{c}\mathrm{H}_{\mathrm{o}}: \mu_{5}=\mu_{6}=\mu_{7}=\mu_{8}=\mu_{9} \\
\mathrm{H}_{1:} \text { at least two means are unequal }\end{array}$ & 8.83 & 0.001 & Significant \\
\hline
\end{tabular}

Designate: $\mathrm{H}_{\mathrm{o}}=$ Null hypothesis (All means are equal), $\mathrm{H}_{1}=$ Alternate hypothesis (At least two means are unequal), $\mu_{1}, \mu_{2}, \mu_{3}$ and $\mu_{3}=$ Population mean of bacterial strains, $\mu_{5}, \mu_{6}, \mu_{7}, \mu_{8}, \mu_{9}=$ Population mean of initial motor oil concentration, $\mu_{10}=\mu_{11}=\mu_{12}=$ Population mean of different $\mathrm{pH}, \mu_{13}=\mu_{14}=\mu_{15}=$ Population mean of different temperatures, $\mu_{16}=\mu_{17}=\mu_{18}=\mu_{19}=$ Population mean of different incubation time, $\mu_{20}=\mu_{21}=$ Population mean of SDS concentrations 


\section{Extraction and characterization of biosurfactants}

The test bacterial strains were investigated for possible biosurfactant secretions in its culture media up to $96 \mathrm{~h}$ of incubation. After solvent extraction, we obtained the crude biosurfactant yields of $0.9,1.8,1.6,1.7 \mathrm{~g} \mathrm{~L}^{-1}$, respectively, with Staphylococcus hominis, Staphylococcus sp., Bacillus flexus, and Bacillus oceanisediminus strains. Previously, a bacterial strain of Bacillus licheniformis resulted in $1.28 \mathrm{~g} \mathrm{~L}^{-1}$ of biosurfactant (Kumar et al., 2016). Likewise, Bacillus subtilus had been reported to produce $3.24 \mathrm{~g} \mathrm{~L}^{-1}$ of biosurfactant (Nayarisseri et al., 2018). The bacterial strain of Staphylococcus sp. had been reported to produce $2.1 \mathrm{~g} \mathrm{~L}^{-1}$ biosurfactant (Eddouaouda et al., 2012). The biosurfactant produced from Staphylococcus sp., being the highest motor oil degrader and biosurfactant producer, was investigated using the FTIR analysis. The FTIR spectrum of biosurfactant collected from the Staphylococcus sp. is shown in Fig. 9. A sharp absorbance peak at $3292 \mathrm{~cm}^{-1}$ confirmed the existence of - $\mathrm{NH}$ and - $\mathrm{OH}$ functional groups in the biosurfactant, which indicated the presence of amino groups in the product. Other peaks at 2956, 2925, and $2854 \mathrm{~cm}^{-1}$ confirmed the existence of $-\mathrm{C}-\mathrm{CH}_{3}$ vibrations. The presence of a peak at $1664 \mathrm{~cm}^{-1}$ indicated the CO-N stretching vibrations which are similar to the lactone ring present in the lipopeptides. The presence of peaks at 1456 and $1406 \mathrm{~cm}^{-1}$ corresponded to $-\mathrm{C}-\mathrm{CH}_{2}$ and $-\mathrm{C}-\mathrm{CH}_{3}$ vibrations of aliphatic chains, respectively. The peak at $1194 \mathrm{~cm}^{-1}$ indicated the probable existence of $\mathrm{C}-\mathrm{O}-\mathrm{C}$ vibration of the ester linkage. The results demonstrate that the biosurfactant produced from the bacterial strain of Staphylococcus sp. was a lipopeptide.

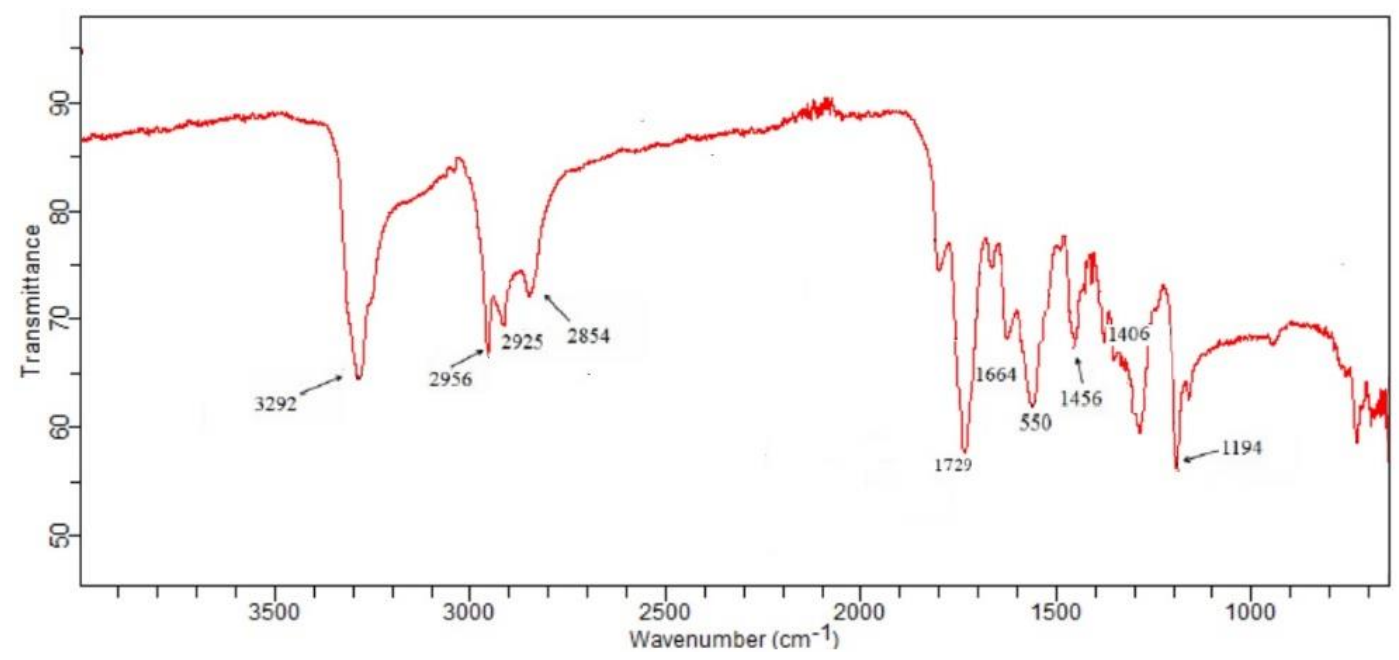

Figure 9. Representative FTIR spectrum of the biosurfactant isolated from Staphylococcus sp.

\section{Conclusion}

The isolated and identified non-Pseudomonads at different motor oil concentrations, $\mathrm{pH}$, temperatures, incubation time, and parameters showed different levels of biodegradation. The trend of higher biodegradation was observed at low motor oil concentrations while a higher concentration of motor oil declined the bacterial growth. The biosurfactants behaved more effectively in the neutral medium as compared to in the acidic or alkaline media. The SDS and Cr(VI) ions inhibited the process of motor oil biodegradation in the presence of microbial isolates. It was concluded that the identified 
non-Pseudomonads isolated from soil of auto workshops could effectively be employed for successful biodegradation of motor oil and its biotransformation into biosurfactants. The future developments in this area might be to further tune the biosurfactant-producing strains for enhanced yields and to obtain particular congeners using the advanced techniques of synthetic and molecular biology. The bacterial consortia may also be investigated for enhanced remediation of crude oils contaminated soils.

Acknowledgment. The authors acknowledge the financial support of the Higher Education Commission, Islamabad for pursuing this study.

Conflict of interests. The authors declared that they have no conflict of interests.

Ethical statement. This article does not contain any studies with human participants or animals performed by any of the authors.

\section{REFERENCES}

[1] Abid, S., Raza, Z. A., Hussain, T. (2016): Production kinetics of polyhydroxyalkanoates by using Pseudomonas aeruginosa gamma ray mutant strain EBN-8 cultured on soybean oil. - 3 Biotech 6(2): 1-10.

[2] Batista, S., Mounteer, A., Amorim, F., Totola, M. (2006): Isolation and characterization of biosurfactant/bioemulsifier-producing bacteria from petroleum contaminated sites. Bioresource technology 97(6): 868-875.

[3] Bayat, Z., Hassanshahian, M., Hesni, M. A. (2015): Enrichment and isolation of crude oil degrading bacteria from some mussels collected from the Persian Gulf. - Marine pollution bulletin 101(1): 85-91.

[4] Behera, I. D., Nayak, M., Biswas, S., Meikap, B. C., Sen, R. (2021): Enhanced biodegradation of total petroleum hydrocarbons by implementing a novel two-step bioaugmentation strategy using indigenous bacterial consortium. - Journal of Environmental Management 292: 112746.

[5] Bhattacharya, M., Guchhait, S., Biswas, D., Singh, R. (2019): Evaluation of a microbial consortium for crude oil spill bioremediation and its potential uses in enhanced oil recovery. - Biocatalysis and agricultural biotechnology 18: 101034.

[6] Bossert, I., Bartha, R. (1984): The fate of petroleum in soil ecosystems. - New York (USA), Macmillan.

[7] Cameotra, S. S., Singh, P. (2009): Synthesis of rhamnolipid biosurfactant and mode of hexadecane uptake by Pseudomonas species. - Microbial cell factories 8(1): 1-7.

[8] Carrillo, P., Mardaraz, C., Pitta-Alvarez, S., Giulietti, A. (1996): Isolation and selection of biosurfactant-producing bacteria. - World Journal of Microbiology and Biotechnology 12(1): 82-84.

[9] Cooper, D. G., Goldenberg, B. G. (1987): Surface-active agents from two Bacillus species. - Applied and environmental microbiology 53(2): 224-229.

[10] da Silva, I. A., Bezerrac, K. G. O., Batista, I. J. (2020): Evaluation of the emulsifying and antioxidant capacity of the biosurfactant produced by Candida bombicola URM 3718. Chemical Engineering 79(1): 67-72.

[11] Dhote, M., Kumar, A., Juwarkar, A. (2018): Petroleum contaminated oil sludge degradation by defined consortium: Influence of biosurfactant production. - Proceedings of the National Academy of Sciences, India Section B: Biological Sciences 88(2): 517-523.

[12] Duan, L., Naidu, R., Thavamani, P., Meaklim, J., Megharaj, M. (2015): Managing longterm polycyclic aromatic hydrocarbon contaminated soils: a risk-based approach. Environmental Science and Pollution Research 22(12): 8927-8941. 
[13] Eddouaouda, K., Mnif, S., Badis, A., Younes, S. B., Cherif, S., Ferhat, S., Mhiri, N., Chamkha, M., Sayadi, S. (2012): Characterization of a novel biosurfactant produced by Staphylococcus strain 1E with potential application on hydrocarbon bioremediation. Journal of Basic Microbiology 52(4): 408-418.

[14] El-Sayed, A., Shebl, A., Ramadan, M. (1995): Laboratory study of microbial cleaning of oil spills under Saudi environmental conditions. - Middle East Oil Show, 1995. Society of Petroleum Engineers.

[15] Gao, C. (2018): Experiences of microbial enhanced oil recovery in Chinese oil fields. Journal of Petroleum Science and Engineering 166: 55-62.

[16] Gregorich, E., Gillespie, A., Beare, M., Curtin, D., Sanei, H., Yanni, S. (2015): Evaluating biodegradability of soil organic matter by its thermal stability and chemical composition. - Soil Biology and Biochemistry 91: 182-191.

[17] Henkel, M., Hausmann, R. (2019): Diversity and classification of microbial surfactants. Biobased surfactants, Chapter 2, Elsevier, pp. 41-63.

[18] Javed, S., Sarwar, A., Tassawar, M., Faisal, M. (2015): Conversion of selenite to elemental selenium by indigenous bacteria isolated from polluted areas. - Chemical Speciation \& Bioavailability 27(4): 162-168.

[19] John, W. C., Ogbonna, I. O., Gberikon, G. M., Iheukwumere, C. C. (2021): Evaluation of biosurfactant production potential of Lysinibacillus fusiformis MK559526 isolated from automobile-mechanic-workshop soil. - Brazilian Journal of Microbiology 52(2): 663-674.

[20] Kanmani, P., DivyaSri, E., Rajakarvizhi, R., Senthamil, O., Sivasankari, V., Aravind, J. (2017): Optimization of biosurfactant production and crude oil emulsification by Bacillus sp. isolated from hydrocarbon contaminated soil sample. - In: Bioremediation and Sustainable Technologies for Cleaner Environment, Springer, pp. 305-317.

[21] Kao, C., Liu, J., Chen, Y., Chai, C., Chen, S. (2005): Factors affecting the biodegradation of PCP by Pseudomonas mendocina NSYSU. - Journal of hazardous materials 124(1-3): 68-73.

[22] Karlapudi, A. P., Venkateswarulu, T., Tammineedi, J., Kanumuri, L., Ravuru, B. K., Ramu Dirisala, V., Kodali, V. P. (2018): Role of biosurfactants in bioremediation of oil pollutiona review. - Petroleum 4(3): 241-249.

[23] Khubaib, M. A., Raza, Z. A., Abid, S., Nazir, A., Tariq, M. R. (2021): Cell-Free Culture Broth of Pseudomonas aeruginosa - an alternative source of biodispersant to synthetic surfactants for dyeing the polyester fabric. - Journal of Surfactants and Detergents 24(2): 343-355.

[24] Kumar, A. P., Janardhan, A., Viswanath, B., Monika, K., Jung, J.-Y., Narasimha, G. (2016): Evaluation of orange peel for biosurfactant production by Bacillus licheniformis and their ability to degrade naphthalene and crude oil. - 3 Biotech 6(1): 43-53.

[25] Kumar, S., Stecher, G., Li, M., Knyaz, C., Tamura, K. (2018): MEGA X: molecular evolutionary genetics analysis across computing platforms. - Molecular Biology and Evolution 35(6): 1547-1549.

[26] Miranda, C., Castillo, G. (1998): Resistance to antibiotic and heavy metals of motile aeromonads from Chilean freshwater. - Science of the Total Environment 224(1-3): 167176.

[27] Naik, S. N., Saxena, D. K., Dole, B. R., Khare, S. K. (2018): Potential and perspective of castor biorefinery. - Waste Biorefinery, Chapter 21, Elsevier, pp. 623-656.

[28] Nandiyanto, A. B. D., Oktiani, R., Ragadhita, R. (2019): How to read and interpret FTIR spectroscope of organic material. - Indonesian Journal of Science and Technology 4(1): 97-118.

[29] Nayarisseri, A., Singh, P., Singh, S. K. (2018): Screening, isolation and characterization of biosurfactant producing Bacillus subtilis strain ANSKLAB03. - Bioinformation 14(6): 304-314. 
[30] Palanisamy, N., Ramya, J., Kumar, S., Vasanthi, N., Chandran, P., Khan, S. (2014): Diesel biodegradation capacities of indigenous bacterial species isolated from diesel contaminated soil. - Journal of Environmental Health science and Engineering 12(1): 1-8.

[31] Paniagua-Michel, J., Rosales, A. (2015): Marine bioremediation - a sustainable biotechnology of petroleum hydrocarbons biodegradation in coastal and marine environments. - Journal of Bioremediation \& Biodegredation 6(2): 1-6.

[32] Pinazo, A., Pérez, L., del Carmen Morán, M., Pons, R. (2019): Arginine - based surfactants: synthesis, aggregation properties, and applications. - Biobased Surfactants, Chapter 13, Elsevier, pp. 413-445.

[33] Rahman, K., Rahman, T. J., McClean, S., Marchant, R., Banat, I. M. (2002): Rhamnolipid biosurfactant production by strains of Pseudomonas aeruginosa using low-cost raw materials. - Biotechnology Progress 18(6): 1277-1281.

[34] Raza, Z. A., Khan, M. S., Khalid, Z. M. (2007): Evaluation of distant carbon sources in biosurfactant production by a gamma ray-induced Pseudomonas putida mutant. - Process Biochemistry 42(4): 686-692.

[35] Raza, Z. A., Khalid, Z. M., Banat, I. M. (2009): Characterization of rhamnolipids produced by a Pseudomonas aeruginosa mutant strain grown on waste oils. - Journal of Environmental Science and Health, Part A, 44(13): 1367-1373.

[36] Ren, J., Fan, B., Niu, D., Gu, Y., Li, C. (2021): Biodegradation of waste cooking oils by Klebsiella quasivariicola IUMR-B53 and characteristics of its oil-degrading enzyme. Waste and Biomass Valorization 12: 1243-1252.

[37] Rita de Cássia, F., Luna, J. M., Rufino, R. D., Sarubbo, L. A. (2021): Ecotoxicity of the formulated biosurfactant from Pseudomonas cepacia CCT 6659 and application in the bioremediation of terrestrial and aquatic environments impacted by oil spills. - Process Safety and Environmental Protection 154: 338-347.

[38] Sakamoto, K., Lochhead, R., Maibach, H., Yamashita, Y. (2017): Cosmetic Science and Technology: theoretical Principles and Applications. - Elsevier.

[39] Sharma, S., Verma, R., Pandey, L. M. (2019): Crude oil degradation and biosurfactant production abilities of isolated Agrobacterium fabrum SLAJ731. - Biocatalysis and Agricultural Biotechnology 21(1): 101322-101331.

[40] Siegmund, I., Wagner, F. (1991): New method for detecting rhamnolipids excreted by Pseudomonas species during growth on mineral agar. - Biotechnology Techniques 5(4): 265-268.

[41] Singh, S., Kumar, V., Singh, S., Dhanjal, D. S., Datta, S., Sharma, D., Singh, N. K., Singh, J. (2020): Biosurfactant-based bioremediation. - Bioremediation of Pollutants, Chapter 16, Elsevier, pp. 333-358.

[42] Sivagamasundari, T. (2017): Optimization of Diesel oil degrading Bacterial strains at various culture parameters. - International Journal of Research and Development in Pharmacy \& Life Sciences 6(6): 2840-2844.

[43] Trellu, C., Mousset, E., Pechaud, Y., Huguenot, D., Van Hullebusch, E. D., Esposito, G., Oturan, M. A. (2016): Removal of hydrophobic organic pollutants from soil washing/flushing solutions: a critical review. - Journal of Hazardous Materials 306: 149-174.

[44] Vandenbergh, P. A., Gonzalez, C. F. (1984): Method for protecting the growth of plants employing mutant siderophore producing strains of Pseudomonas putida. - Google Patents, PubChem.

[45] Varadavenkatesan, T., Murty, V. R. (2013): Production of a lipopeptide biosurfactant by a novel Bacillus sp. and its applicability to enhanced oil recovery. - International Scholarly Research Notices, Article ID: 621519.

[46] Vijayakumar, S., Saravanan, V. (2015): Biosurfactants-types, sources and applications. Research Journal of Microbiology 10(5): 181-192.

[47] Zhao, F., Shi, R., Zhao, J., Li, G., Bai, X., Han, S., Zhang, Y. (2015): Heterologous production of Pseudomonas aeruginosa rhamnolipid under anaerobic conditions for microbial enhanced oil recovery. - Journal of Applied Microbiology 118(2): 379-389. 


\section{APPENDIX}

Table S1. Emulsification index $\left(E_{24}\right)$ vs. petrol at $25^{\circ} \mathrm{C}$, and the morphological and biochemical characterization of indigenous bacterial isolates

\begin{tabular}{|c|c|c|c|c|c|c|c|c|c|c|c|c|}
\hline \multirow{3}{*}{ Isolate } & \multirow{3}{*}{$\mathbf{E}_{24}(\%)$} & \multicolumn{5}{|c|}{ Morphological characterization } & \multicolumn{6}{|c|}{ Biochemical characterization } \\
\hline & & \multirow{2}{*}{$\begin{array}{l}\text { Gram } \\
\text { stain }\end{array}$} & \multirow[t]{2}{*}{ Spore stain } & \multirow{2}{*}{\multicolumn{2}{|c|}{ Cell shape Catalase test }} & \multirow[t]{2}{*}{ Oxidase test } & \multirow[t]{2}{*}{ Motility test } & \multirow{2}{*}{$\begin{array}{l}\text { Methyl red } \\
\text { test }\end{array}$} & \multirow[t]{2}{*}{ Indole test } & \multirow{2}{*}{$\begin{array}{c}\text { Mannitol salt } \\
\text { agar test }\end{array}$} & \multicolumn{2}{|c|}{$\begin{array}{c}\text { Triple sugar iron } \\
\text { test }\end{array}$} \\
\hline & & & & & & & & & & & slant & butt \\
\hline F1 & $87 \pm 10$ & + & -ve & Cocci & $+\mathrm{ve}$ & -ve & $+\mathrm{ve}$ & $+\mathrm{ve}$ & -ve & + ve & $\mathrm{Y}$ & $\mathrm{Y}$ \\
\hline F9 & $81 \pm 10$ & + & -ve & Cocci & $+\mathrm{ve}$ & -ve & $+\mathrm{ve}$ & $+\mathrm{ve}$ & -ve & $+\mathrm{ve}$ & $\mathrm{Y}$ & $\mathrm{Y}$ \\
\hline F19 & $40 \pm 6$ & + & -ve & Cocci & $+\mathrm{ve}$ & -ve & $+\mathrm{ve}$ & $+\mathrm{ve}$ & -ve & $+\mathrm{ve}$ & $\mathrm{Y}$ & $\mathrm{Y}$ \\
\hline S6 & $42 \pm 5$ & + & + & Rods & $+\mathrm{ve}$ & -ve & -ve & $+\mathrm{ve}$ & -ve & -ve & $\mathrm{Y}$ & $\mathrm{R}$ \\
\hline SJ1 & $49 \pm 12$ & + & + & Rods & $+\mathrm{ve}$ & -ve & -ve & -ve & -ve & -ve & $\mathrm{Y}$ & $\mathrm{R}$ \\
\hline SJ4 & $41 \pm 10$ & + & +ve & Rods & $+v e$ & -ve & $+v e$ & $+v e$ & -ve & -ve & $\mathrm{Y}$ & $\mathrm{Y}$ \\
\hline SJ10 & $43 \pm 8$ & + & + & Rods & $+\mathrm{ve}$ & $+\mathrm{ve}$ & -ve & -ve & -ve & -ve & $\mathrm{Y}$ & $\mathrm{Y}$ \\
\hline SJ12 & $31 \pm 16$ & + & -ve & Cocci & -ve & +ve & $+\mathrm{ve}$ & -ve & -ve & -ve & $\mathrm{Y}$ & $\mathrm{R}$ \\
\hline SJ15 & $48 \pm 14$ & + & + & Rods & $+v e$ & -ve & -ve & -ve & -ve & -ve & $\mathrm{Y}$ & $\mathrm{R}$ \\
\hline SJ17 & $40 \pm 7$ & + & + & Rods & $+\mathrm{ve}$ & -ve & -ve & -ve & -ve & -ve & $\mathrm{Y}$ & $\mathrm{R}$ \\
\hline SJ19 & $46 \pm 9$ & + & + & Rods & $+\mathrm{ve}$ & -ve & -ve & -ve & -ve & -ve & $\mathrm{Y}$ & $\mathrm{R}$ \\
\hline SJ20 & $91 \pm 11$ & + & + & Rods & $+\mathrm{ve}$ & -ve & $+v e$ & -ve & -ve & -ve & $\mathrm{Y}$ & $\mathrm{R}$ \\
\hline SJ32 & $88 \pm 8$ & + & + & Rods & $+\mathrm{ve}$ & -ve & $+\mathrm{ve}$ & -ve & -ve & -ve & $\mathrm{Y}$ & $\mathrm{R}$ \\
\hline SJ36 & $42 \pm 6$ & + & + & Rods & $+\mathrm{ve}$ & -ve & $+\mathrm{ve}$ & -ve & -ve & -ve & $\mathrm{Y}$ & $\mathrm{R}$ \\
\hline SJ37 & $41 \pm 8$ & + & -ve & Rods & $+v e$ & -ve & -ve & $+v e$ & -ve & -ve & $\mathrm{Y}$ & $\mathrm{Y}$ \\
\hline SJ39 & $47 \pm 12$ & + & -ve & Cocci & $+\mathrm{ve}$ & -ve & $+\mathrm{ve}$ & $+\mathrm{ve}$ & -ve & $+\mathrm{ve}$ & $\mathrm{Y}$ & $\mathrm{Y}$ \\
\hline SJ40 & $46 \pm 13$ & + & + & Rods & $+\mathrm{ve}$ & -ve & $+\mathrm{ve}$ & $+\mathrm{ve}$ & -ve & -ve & $\mathrm{Y}$ & $\mathrm{Y}$ \\
\hline SJ41 & $38 \pm 7$ & + & + & Rods & $+\mathrm{ve}$ & $+v e$ & $+\mathrm{ve}$ & -ve & -ve & -ve & $\mathrm{Y}$ & $\mathrm{R}$ \\
\hline SU2 & $40 \pm 9$ & + & -ve & Rods & $+\mathrm{ve}$ & $+\mathrm{ve}$ & -ve & -ve & -ve & -ve & $\mathrm{R}$ & $\mathrm{Y}$ \\
\hline U8 & $45 \pm 9$ & + & + & Rods & $+v e$ & -ve & -ve & -ve & -ve & -ve & $\mathrm{Y}$ & $\mathrm{R}$ \\
\hline
\end{tabular}


Table S2. Antibiotic (at $20 \mu \mathrm{g} / \mathrm{mL}$ ) resistance and heavy metal resistant profiles of the selected strains

\begin{tabular}{|c|c|c|c|c|c|c|c|c|c|c|c|c|}
\hline \multirow{2}{*}{ Code } & \multirow{2}{*}{ Strain } & \multicolumn{5}{|c|}{$\begin{array}{l}\text { Antibiotic resistance (Inhibition zones, } \\
\text { mm) }\end{array}$} & \multicolumn{5}{|c|}{ Heavy metal resistance $(\mu \mathrm{g} / \mathrm{ml})$} & \multirow{2}{*}{ Order of metal resistance } \\
\hline & & $\mathrm{S}$ & $\mathrm{AM}$ & $\mathrm{TE}$ & $\mathrm{K}$ & $\mathrm{E}$ & $\mathrm{Zn}^{+2}$ & $\mathrm{~Pb}^{+2}$ & $\mathrm{Co}^{+2}$ & $\mathrm{Mn}^{+2}$ & $\mathrm{Ni}^{+2}$ & \\
\hline F1 & $\begin{array}{c}\text { Staphylococcus } \\
\text { hominis }\end{array}$ & $17 \pm 1$ & $30 \pm 2$ & $27 \pm 2$ & $18 \pm 2$ & $11 \pm 2$ & 1,000 & 40,000 & 1,000 & 10,000 & 5,000 & $\mathrm{~Pb}^{+2}>\mathrm{Mn}^{+2}>\mathrm{Ni}^{+2}>\mathrm{Co}^{+2}, \mathrm{Zn}^{+2}$ \\
\hline F9 & Staphylococcus sp. & $15 \pm 2$ & $25 \pm 2$ & $27 \pm 4$ & $14 \pm 2$ & $19 \pm 2$ & 700 & 20,000 & 800 & 8,000 & 1,000 & $\mathrm{~Pb}^{+2}>\mathrm{Mn}^{+2}>\mathrm{Ni}^{+2}>\mathrm{Co}^{+2}>\mathrm{Zn}^{+2}$ \\
\hline SJ20 & Bacillus flexus & $23 \pm 2$ & $27 \pm 4$ & $32 \pm 3$ & $20 \pm 3$ & $7 \pm 5$ & 500 & 15,000 & 500 & 5,000 & 2,000 & $\mathrm{~Pb}^{+2}>\mathrm{Mn}^{+2}>\mathrm{Ni}^{+2}>\mathrm{Co}^{+2}, \mathrm{Zn}^{+2}$ \\
\hline SJ32 & $\begin{array}{c}\text { Bacillus } \\
\text { Oceanisediminis }\end{array}$ & $11 \pm 3$ & $11 \pm 4$ & $24 \pm 4$ & 0 & $15 \pm 4$ & 700 & 30,000 & 700 & 9,000 & 4,000 & $\mathrm{~Pb}^{+2}>\mathrm{Mn}^{+2}>\mathrm{Ni}^{+2}>\mathrm{Co}^{+2}, \mathrm{Zn}^{+2}$ \\
\hline
\end{tabular}

Note: $\mathrm{S}=$ streptomycin, $\mathrm{AM}=$ ampicillin, $\mathrm{T}=$ tetracycline, $\mathrm{K}=$ kanamycin, $\mathrm{E}=$ erythromycin, and $\mathrm{C}=$ chloramphenicol 
(a)

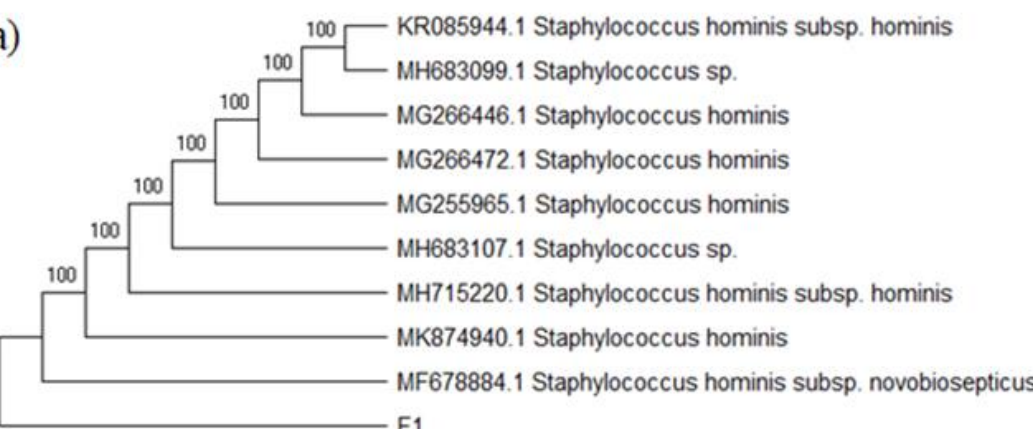
F1

(c)

\begin{tabular}{|l} 
KX622621.1 Bacillus sp. \\
\hline KY085978.1 Bacillus flexus \\
MG407663.1 Bacillus flexus \\
MG595382.1 Bacillus flexus \\
MH819942.1 Bacillus sp. (in: Bacteria) \\
MH819943.1 Bacillus sp. (in: Bacteria) \\
MH371777.1 Bacillus flexus \\
LC512759.1 Bacillus flexus
\end{tabular}

(b)

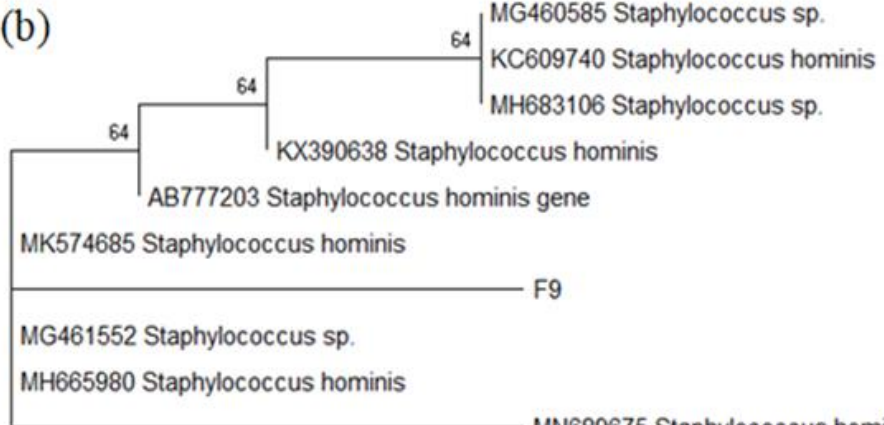

MN689675 Staphylococcus hominis subsp. hominis

0.00010

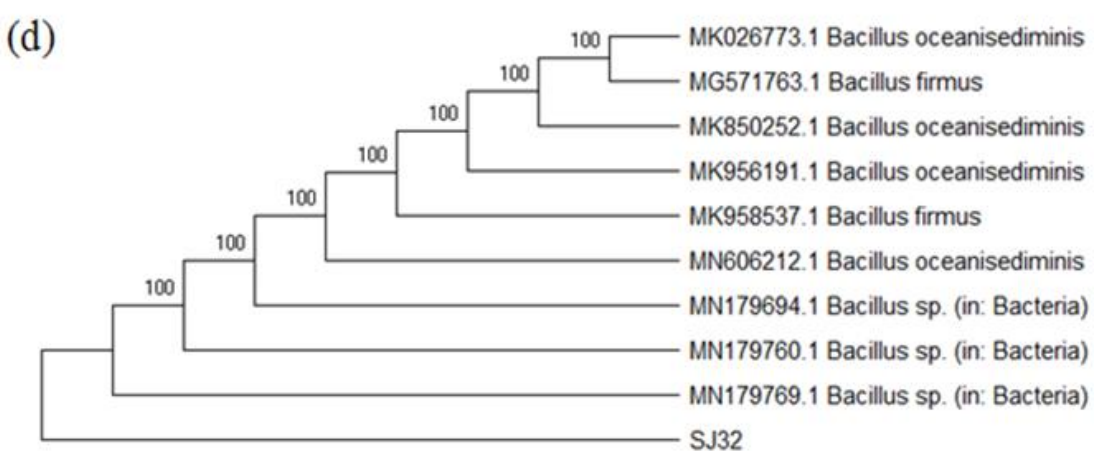

0.00010

Figure S1. Phylogenetic trees of selected bacterial strains of (a) F1, (b) F9, (c) SJ20, and (d) SJ32 

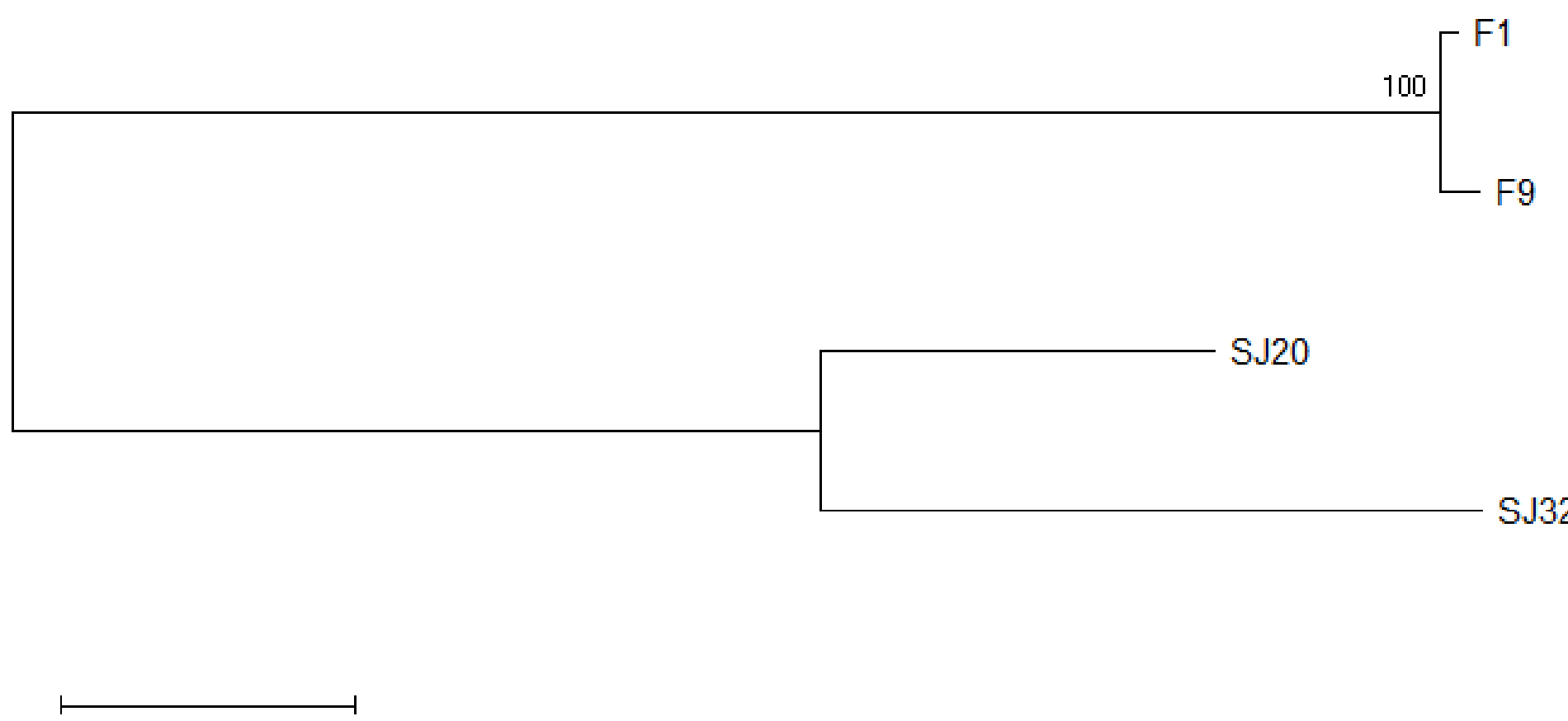

0.010

Figure S2. 16 Sr RNA sequencing of the selected strains

APPLIED ECOLOGY AND ENVIRONMENTAL RESEARCH 20(1):79-102

http://www.aloki.hu • ISSN 15891623 (Print) • ISSN1785 0037 (Online)

DOI: http://dx.doi.org/10.15666/aeer/2001_079102

(c) 2022, ALÖKI Kft., Budapest, Hungary 